\title{
COMMENTARY
}

\section{IS INTERNATIONAL LAW REALLY STATE LAW?}

\author{
Harold Hongju Koh*
}

\begin{abstract}
Revisionist scholars have recently challenged the hormbook rule that United States federal courts shall determine questions of customary international law as federal law. The revisionists claim that the traditional rule violates constitutional history and doctrine, and offends fundamental principles of separation of powers, federalism, and democracy. Professor Koh rebuts the revisionist challenge, applying each of the revisionists' oun stated criteria. He demonstrates that the lawful and sensible practice of treating international law as federal law should be left undisturbed by both the political and judicial branches.
\end{abstract}

\section{How should we understand the following passages?}

[W]e are constrained to make it clear that an issue concerned with a basic choice regarding the competence and function of the Judiciary and the National Executive in ordering our relationships with other members of the international community must be treated exclusively as an aspect of federal law. ${ }^{1}$

Customary international law is federal law, to be enunciated authoritatively by the federal courts. ${ }^{2}$

International human rights cases predictably raise legal issues - such as interpretations of international law - that are matters of Federal common law and within the particular expertise of Federal courts. ${ }^{3}$

Taking these passages at face value, most readers would understand them to mean just what they say: judicial determinations of international law - including international human rights law - are matters of federal law. That these three declarations emanate from the

* Gerard C. and Bernice Latrobe Smith Professor of International Law and Director, Orville H. Schell, Jr. Center for International Human Rights, Yale Law School.

I am grateful to Mark Templeton for excellent research assistance, to Gene Coakley and Renee DeMatteo for selfless support, and to Akhil Amar, Drew Days, Bill Dodge, Bob Ellickson, John Hart Ely, Dick Fallon, Willy Fletcher, Ryan Goodman, Louis Henkin, Derek Jinks, Paul Kahn, Larry Lessig, Gerry Neuman, David Shapiro, David Strauss, and Kenji Yoshino for incisive comments. I should note that I have participated in a number of the lawsuits discussed in this essay as a government or private attorney. See Kadic v. Karadzic, 7o F.3d 232 (2d Cir. I995) (cocounsel for Doe plaintiffs); Brief for United States as Amicus Curiae at r, Tel-Oren v. Libyan Arab Republic, 470 U.S. 1003 (1985) (No. 83-2052) (co-author), reprinted in 24 I.L.M. 427, 427 (I985). I have also participated as a discussion leader in the Aspen Institute Seminar for Judges on International Human Rights Law: Its Application in National Jurisprudence. See infra note I92.

1 Banco Nacional de Cuba v. Sabbatino, 376 U.S. 398, 425 (I964) (emphasis added).

2 Brief for the United States as Amicus Curiae at I, Filartiga v. Pena-Irala, 630 F.2d 876 (2d Cir. 1980) (No. 79-6090) (emphasis added), reprinted in Ig I.L.M. 585, 606 n.49 (1980).

3 S. REP. No. 102-249, at 6 n.6 (I99I) (emphasis added) (explaining the Torture Victim Protection Act (TVPA) of I99I, 28 U.S.C. § I350 note (I994)). 
federal judicial, executive, and legislative branches, respectively, only confirms the unanimity of relevant opinion on the subject.

As so often happens, the hornbook rule - international law, as applied in the United States, must be federal law - makes obvious sense. Every schoolchild knows that the failures of the Articles of Confederation led to the framing of the Constitution, which established national governmental institutions to articulate uniform positions on such uniquely federal matters as foreign affairs and international law. ${ }^{4}$ Even as the new Constitution withheld foreign affairs powers from the states, ${ }^{5}$ it authorized a national institution, Congress, "[t]o define and punish ... Offences against the Law of Nations."6 But Congress's authority to construe the law of nations was never exclusive. ${ }^{7}$ The early Supreme Court spent much of its time deciding cases under the law of nations. ${ }^{8}$ International law came to occupy "an

4 See The Federalist No. 42, at 264 (James Madison) (Clinton Rossiter ed., I96I) ("If we are to be one nation in any respect, it clearly ought to be in respect to other nations."). Both Edmund Randolph and James Madison complained at the Constitutional Convention about the Continental Congress's inability to give effect to the law of nations under the Articles of Confederation. See Frederick W. MARKS III, INDEPENDENCE ON TrIal: Foreign AFFairs AND the Making of the Constitution I45 (2d ed. I986); Jack N. Rakove, Original Meanings: Politics and IDEas In the Making of the Constitution 29 (I996); I The RECORDS OF THE FEDERAL CONVENTION OF 1787, at 24-25, 3I6-I7 (Max Farrand ed., I937).

5 The Constitution bars states from making treaties, alliances, agreements, or compacts with foreign powers without the consent of Congress. It also bars them from engaging in war unless invaded, and forbids them to lay imposts or duties on imports or expcrts without the consent of Congress. See U.S. CoNST. art. I, § IO. In addition, the Constitution declares the law and treaties of the United States to be supreme over contrary state law. See id. art. VI, § 2. Throughout this essay, I capitalize "State" when referring to nation-states, and use the lower case when referring to a state of the federal union of the United States.

6 Id. art. I, $\$ 8$, cl. Io. For a history of this clause, see Charles D. Siegal, Deference and Its Dangers: Congress' Power to "Define ... Offenses Against the Law of Nations", 2 I VAND. J. TRANSNAT'L L. 865 (I988). No less an originalist than Robert Bork acknowledges that this provision was motivated by the Framers' recognition that "[i]mplementation of the law of nations by the American government was ... crucial to the conduct of our foreign relations, a subject of pervasive concern in the Constitution." Finzer v. Barry, 798 F.2d I450, I455 (D.C. Cir. I986) (Bork, J.), aff'd in part and rev'd in part sub nom., Boos v. Barry, 485 U.S. 3 I2 (I988).

7 In 1789 , the Continental Congress expressly resolved that the United States would cause the "law of nations to be most strictly observed." I4 JOURNALS OF THE CONTINENTAL CONGRESS I774-I789, at 635 (1909). The Framers never suggested, however, that the federal courts' power to construe customary international law should be somehow subordinated to the concurrent authority of the political branches to define the law of nations. See, e.g., THE FEDERAList No. 64, at 394 (John Jay) (Clinton Rossiter ed., I96I) ("All constitutional acts of power, whether in the executive or in the judicial department, have as much legal validity and obligation as if they proceeded from the legislature.").

8 See, e.g., Chisholm v. Georgia, 2 U.S. (2 Dall.) 4 I9, 474 (I793) ("[T]he United States had, by taking a place among the nations of the earth, become amenable to the laws of nations...."). In 1815, Chief Justice Marshall declared that "the Court is bound by the law of nations which is a part of the law of the land." The Nereide, I3 U.S. (9 Cranch) 388,423 (I8I5) (emphasis added). It seems unlikely that the Chief Justice would have understood the Supreme Court to be "bound by the law of nations" had that law merely represented the law of the several states. Nor, given the attention paid by the Marshall Court to piracy cases, the precursors of modern human rights cases, is it plausible to argue that U.S. courts have only recently begun to enforce human rights 
existence in the federal courts independent of acts of Congress." $\mathrm{By}$ I98I, the Supreme Court had come unanimously to "recogniz[e] the need and authority in some limited areas to formulate what has come to be known as 'federal common law" in cases in which "a federal rule of decision is 'necessary to protect uniquely federal interests," including "international disputes implicating ... our relations with foreign nations."10

There matters stood until the last volume of this Law Review, when Professors Curtis Bradley and Jack Goldsmith launched an energetic assault upon this body of settled law. ${ }^{11}$ In Customary International Law as Federal Common Law: A Critique of the Modern Position, Bradley and Goldsmith argue that the "ascendancy of CIL [their term for customary international law] to the status of federal common law" is of recent vintage. ${ }^{22}$ The federalization of customary international law, they claim, stems not from traditional constitutional concerns about supremacy, uniformity, and the federal interest in international affairs, but rather from "a combination of troubling developments, including mistaken interpretations of history, doctrinal bootstrapping by the Restatement (Third) of Foreign Relations Law, and academic fiat." 13 Moreover, they claim, the so-called "modern position" conjured by this academic hijacking operation "depart[s] from well-accepted notions of American representative democracy, federal common law, separation of powers, and federalism."14 In more recent writing, they have extended their challenge into a curious broadside decrying The Current Illegitimacy of International Human Rights Litigation. ${ }^{15}$

norms. See generally G. Edward White, The Marshall Court and International Law: The Piracy Cases, 83 AM. J. INT'L L. 727 (1989) (discussing the attention given by the Marshall Court to international law in piracy cases).

9 Filartiga v. Pena-Irala, 630 F.2d 876, 887 n.2o (2d Cir. I980); accord United States v. Buck, 690 F. Supp. 129I, 1297 (S.D.N.Y. I988). For extensive discussions of the early case law, see Edwin D. Dickinson, The Law of Nations as Part of the National Law of the United States, Ior U. PA. L. REv. 26 (1952); Edwin Dewitt Dickinson, The Law of Nations as Part of the National Law of the United States, II, roI U. PA. L. REV. 792 (1952); and Stewart Jay, The Status of the Law of Nations in Early American Law, 42 VAND. L. REV. 819 (1989).

10 Texas Indus. v. Radcliff Materials, Inc., 45I U.S. 630, 640-4I (I98I) (quoting Banco Nacional de Cuba v. Sabbatino, 376 U.S. 398,426 (rg64)).

11 See Curtis A. Bradley \& Jack L. Goldsmith, Customary International Law as Federal Common Law: A Critique of the Modern Position, IIO HARV. L. REV. 815 (1997) [hereinafter Bradley \& Goldsmith, Customary International Law].

12 Id. at 82 I.

$13 I d$.

14 Id.

15 Curtis A. Bradley \& Jack L. Goldsmith, The Current Illegitimacy of International Human Rights Litigation, 66 FORDHAM L. REV. 3 I9 (1997) [hereinafter Bradley \& Goldsmith, Current Illegitimacy]. 
Bradley and Goldsmith's position is not entirely novel, ${ }^{16}$ and their democracy talk may have superficial appeal for those not well steeped in the fields of international and foreign affairs law. Their antijudicial-activism rhetoric makes for lively and provocative reading, which may account for the academic attention their piece has already attracted. ${ }^{17}$ But even casual reflection compels the conclusion that Bradley and Goldsmith are utterly mistaken.

This Commentary evaluates Bradley and Goldsmith's challenge and demonstrates that it fails on its own terms. Under each of the authors' stated criteria - history and doctrine, separation of powers, federalism, and democratic values ${ }^{18}$ - their position is untenable and certainly far less credible than the traditional view they assail. Even cursory review makes clear that Bradley and Goldsmith have proposed a rather startling nonsolution to a nonproblem. For under current practice, federal courts regularly incorporate norms of customary international law into federal law. Bradley and Goldsmith urge instead a rule whereby "federal courts should not apply [customary international law] as federal law without some authorization to do so by the federal political branches." 19 As we shall see, their rule would foster none of the values that they favor. Instead, their proposal would oust a sensible, settled rule that all three federal branches and the fifty states have consistently followed in favor of a muddled notion that offers only an invitation to chaos.

\section{Bradley and Goldsmith's Proposal}

Bradley and Goldsmith's initial article spends so much time attacking the settled view that customary international law is federal law that it leaves unclear precisely what their alternative might be. Given our three-tiered hierarchy of constitutional, federal, and state law, one might reasonably deduce that if international law is neither constitutional nor federal law, it must be state laze, that is, rules of customary international law may be remade selectively by state legislatures and

16 See, e.g., Phillip R. Trimble, A Revisionist View of Customary International Law, 33 UCLA L. REv. 665 (I986); A.M. Weisburd, State Courts, Federal Courts, and International Cases, 20 YALE J. INT'L L. I (I995).

17 Most of the early commentary has been both critical and, in my view, correct. See, e.g., Ryan Goodman \& Derek P. Jinks, Filartiga's Firm Footing: Intemational Human Rights and Federal Common Lave, 66 ForDhaM L. REV. 463 (I997); Gerald L. Neuman, Sense and Nonsense About Customary International Law: A Response to Professors Bradley and Goldsmith, 66 FORDHAM L. REV. 37 I (1997); Beth Stephens, The Law of Our Land: Customary International Law as Federal Law After Erie, 66 ForDHAM L. REv. 393 (1997). The first response in these pages noted that Bradley and Goldsmith had attempted to make a commonly accepted practice contestable without deeply examining why the proposition that international law is federal law had been deemed incontestable in the first place. See Lawrence Lessig, Erie-Effects of Volume IIo: An Essay on Context in Interpretive Theory, r IO HARV. L. REV. I785, I796-97 (I997).

18 See Bradley \& Goldsmith, Customary International Law, supra note II, at 820-2 I.

19 Bradley \& Goldsmith, Current Illegitimacy, supra note I5, at 349. 
common law decisions. ${ }^{20}$ Yet Bradley and Goldsmith's most recent writing denies that their view "require[s] that CIL be a matter of state common law."21 Instead, they claim, "in most cases, states would rarely incorporate $\mathrm{CIL}$ into state law" and thus "[i]n this circumstance, CII simply would not be a mule of decision in federal court."22

Thus unveiled, the Bradley and Goldsmith position emerges as even more radical than it first appears. For if customary international law is neither federal nor state law (unless specifically incorporated by the state or federal political branches), then in most cases, customary international law is not United States law at all! In effect, Bradley and Goldsmith argue for the near complete ouster of customary international law rules from federal judicial interpretation. Yet such a position would utterly violate "[t]he Framers' Constitution[, which] anticipated that international disputes would regularly come before the United States courts and that the decisions in those cases could rest on principles of international law, without any necessary reference to the common law or to constitutional doctrines."23

At a minimum, one would expect substantial policy justification before such a dramatic reversal of settled doctrine could be asserted by "academic fiat." Yet Bradley and Goldsmith mount virtually no arguments explaining why fifty state courts and legislatures should be free to reject, modify, reinterpret, selectively incorporate, or completely oust customary international law rules from domestic law. Under Bradley and Goldsmith's view, absent an explicit and unambiguous directive from a federal statute or treaty, state courts or legislatures could simply refuse to incorporate into state law customary international rules regarding the non-execution of pregnant women ${ }^{24}$ or the

20 Cf. Bradley \& Goldsmith, Customary International Law, supra note II, at 870 ("If a state chooses to incorporate CIL into state law, then the federal courts would be bound to apply the state interpretation of $\mathrm{CIL}$ on issues not otherwise governed by federal law. If a state did not, in fact, incorporate CII into state law, the federal court would not be authorized to apply CIL as federal or state law.").

21 Bradley \& Goldsmith, Current Illegitimacy, supra note 15, at 349.

22 Id. at 349-50 (emphasis added).

23 White, supra note 8 , at 727 . Moreover, by advocating the elimination of customary international law as a rule of decision in this country, Bradley and Goldsmith propose to nullify the Supreme Court's century-old pronouncement that "[i]nternational law is part of our law, and must be ascertained and administered by the courts of justice of appropriate jurisdiction, as often as questions of right depending upon it are duly presented for their determination." The Paquete Habana, I75 U.S. 677,700 (I900) (emphasis added).

24 Article I(2) of the Senate's reservation to its advice and consent to ratification of the International Covenant on Civil and Political Rights (ICCPR), 999 U.N.T.S. I 7 I (Dec. 19, 1966), purports to preserve the discretion of the United States to impose capital punishment on any duly convicted person "other than a pregnant woman." Reservation No. I, I38 CoNG. REC. S4783 (daily ed. Apr. 2, 1992). Yet another statement attached by the Senate "declares that the provisions of Articles I through 27 of the Covenant [including Article 6.5, the relevant right-to-life pro-

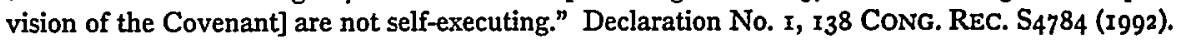
The executive branch has not yet sought any implementing legislation for the ICCPR. 
immunity of visiting heads of state. ${ }^{25}$ Alternatively, each state could adopt its own parochial answer to each of these questions. Thus, for example, the Bradley and Goldsmith theory would allow Massachusetts to deny the customary international law protection of head-ofstate immunity to Queen Elizabeth on tort claims arising out of events in Northern Ireland, whereas the forty-nine other states could choose instead to grant the Queen every conceivable variant of full or partial immunity. ${ }^{26}$ Yet surely, such issues raise precisely the kind of "basic choice regarding the competence and function of the Judiciary and the National Executive in ordering our relationships with other members of the international community" that the Supreme Court held "must be treated exclusively as an aspect of federal law."27

Many scholars question persuasively whether the United States declaration has either domestic or international legal effect. See, e.g., Lori Fisler Damrosch, The Role of the United States Senate Concerning "Self-Executing" and "Non-Self-Executing" Treaties, 67 CHI.-KENT L. REV. 515, 527 (I99I); Louis Henkin, U.S. Ratification of Human Rights Conventions: The Ghost of Senator Bricker, 89 AM. J. INT'L L. 34I, 345-48 (I995). But under Bradley and Goldsmith's analysis, such declarations "make clear that the political branches have not generally authorized the application of the norms embodied in the treaties as domestic federal law." Bradley \& Goldsmith, Customary International Law, supra note $\mathrm{I} \mathrm{I}$, at 870 . Thus, under their reasoning, even if the universal practice among States indicated a customary international law norm against the execution of pregnant women, the legislatures and courts of the states of the United States would be free to ignore that norm.

25 In the United States, head-of-state immunity is a customary international law defense that has been incorporated into federal common law. See, e.g., Suggestion of Immunity of the United States, Domingo v. Marcos, No. C82-1055-V, slip op. (W.D. Wash. Dec. 23, 1982), reprinted in MARIAN NASH (LeICH), DEPARTMENT OF STATE, II Cumulattve Digest of UNITEd STATES PRACTICE IN INTERNATIONAI LAW I98I-1988, at I565 (I988) [hereinafter I988 DigEST OF U.S. PRACTICE] (successfully urging that civil suit against then-Philippine President Ferdinand Marcos be dismissed because "[u]nder customary rules of international law, recognized and applied in the United States, the head of a foreign government, its foreign ministers, and those designated by the head of state as members of his official party are immune from the jurisdiction of the U.S. Federal and State courts").

$26 \mathrm{Or}$, one might imagine a sympathetic state judge or legislator choosing to construe international law to treat escaped Irish Republican Army soldiers as prisoners of war. In United States v. Buck, 690 F. Supp. I29I (S.D.N.Y. I988) (mem.), for example, the defendants moved to dismiss a federal indictment on the grounds that they were immune from prosecution as prisoners of war. See id. at I292. In response to interrogatories from the federal judge, the U.S. attorney asserted that the United States's customary international law obligations regarding prisoner of war status were set forth in Article 4 of the unratified Geneva Convention Relative to the Prisoners of War of August I2, 1949, 6 U.S.T. 33I6, and Protocol I to the Geneva Conventions of 1949, which he claimed only applied during international armed conflicts. See III I988 DIGEST OF U.S. PRACTICE, supra note 25, at 3439 (quoting Memorandum prepared by U.S. Department of State Office of Legal Adviser (Mar. 29, I988), in United States v. Shakur, 690 F. Supp. I29I (S.D.N.Y. r988) (Nos. $84 \mathrm{Cr}$. 220-CSH, SSS 82 Cr. 312-CSH) (calling these provisions "the current obligations of customary international law on according prisoner-of-war status")). See generally Theodor Meron, The Geneva Conventions as Customary Law, 8I AM. J. INT'L L. 348 (1987) (arguing that the Geneva Conventions are declaratory of customary international law). The federal judge accepted the Government's reasoning, and denied defendants' motion to dismiss. See Buck, 690 F. Supp. at I303. But under Bradley and Goldsmith's reasoning, a state judge hearing a similar claim apparently would have been free to redetermine the matter, and the federal courts would thereafter have been bound to follow that result.

27 Banco Nacional de Cuba v. Sabbatino, 376 U.S. 398, 425 (I964). 


\section{HISTORY AND DOCTRINE}

To defend their view, Bradley and Goldsmith first invoke history and doctrine. But their account turns critically on a serious misreading of two landmark Supreme Court cases: Erie Railroad Co. v. Tompkins $^{28}$ and Banco Nacional de Cuba v. Sabbatino. ${ }^{29}$ Because forests have been felled to discuss both cases, I need not describe their broader doctrinal contours here. ${ }^{30}$ Suffice it to say that Bradley and Goldsmith accept that customary international law was part of the English common law that became common law for both the colonies and the fledgling United States. ${ }^{31}$ Until I842, federal and state courts alike construed customary international law with little regard to its federal or state character. Both federal and state courts applied the private international law rules of the law merchant (lex mercatoria) in an effort to construct a uniform national commercial law. ${ }^{32}$ In cases involving admiralty and alien torts, customary international law directly provided the rules of decision for federal courts. ${ }^{33}$

Swift $v$. Tyson ${ }^{34}$ clarified that the bill of exchange rules derived from lex mercatoria constituted part of the "general common law" to

28304 U.S. 64 (1938).

29376 U.S. 398 (I964).

30 For commentary on Erie, see, for example, Akhil Reed Amar, Law Story, Ioz HARV. L. REv. 688, 694-702 (1989); John Hart Ely, The Irrepressible Myth of Erie, 87 HARV. L. REV. 693 (I974); and Henry J. Friendly, In Praise of Erie - and of the New Federal Common Law, 39 N.Y.U. L. REv. 383 (1964). On Sabbatino, see, for example, Louis Henkin, The Foreign Affairs Power of the Federal Courts: Sabbatino, 64 ColUM. L. REv. 805 (1964), and Harold Hongju Koh, Transnational Public Law Litigation, I00 YALE L.J. 2347, 2362-64 (r991).

31 See Bradley \& Goldsmith, Customary Intemational Law, supra note Ir, at 822-23; Louis Henkin, International Law as Law in the United States, 82 Mrch. L. REV. 1555, 1555-6I (I984).

32 See generally R. BRIDwell \& R. WhITTEN, The Constitution aND Common LAw (I977); William A. Fletcher, The General Common Law and Section 34 of the Judiciary Act of 1789: The Example of Marine Insurance, 97 HARV. L. REv. I513 (1984) (arguing that, long before Swift v. Tyson, 4I U.S. (I6 Pet.) I (I842), federal courts employed the general common law as an important part of their working jurisprudence); Stewart Jay, Origins of Federal Common Law (pts. I \& 2), r33 U. PA. L. REv. 1003 , 1042-53 (r985) (discussing the origins of federal common law in the context of political history); Koh, supra note 30 , at $235 \mathrm{I}-58$ (discussing the evolution of American courts' treatment of the law of nations).

33 Admiralty, maritime, and prize cases were heard in federal jurisdiction under the predecessor statute to 28 U.S.C. $\$$ I 333 (I994). Alien tort cases were heard under the Alien Tort Claims Act (ATCA), now codified at 28 U.S.C. $\$$ I350 (I994). See id. ("The district courts shall have original jurisdiction of any civil action by an alien for a tort only, committed in violation of the law of nations or a treaty of the United States."). For a discussion of the relationship between the ATCA and the common law, see William S. Dodge, The Historical Origins of the Alien Tort Statute: A Response to the "Originalists," Ig Hastings INT'L \& CoMp. L. REv. 221, 231-37 (1996). For a discussion of the relationship between the early maritime prize cases and suits under the ATCA, see David J. Bederman, The Feigned Demise of Prize, 9 EMORY INT'L L. REv. 31, 50-69 (I995), reviewing J.H.W. VERZIJL, W.P. HEERE \& J.P.S. OFFERHAUS, INTERNATIONAL LAW IN Historical Perspective, Vol. in, Part IX-c: The Law of Maritime Prize (I992). As Bederman explains, "from time immemorial, when a national court adjudicated a case of a maritime capture it was obliged to follow international law." Id. at $5 \mathrm{x}$.

34 II U.S. (I6 Pet.) I (1842). 
be interpreted by federal courts sitting in diversity jurisdiction. ${ }^{35}$ Thereafter, federal courts construed both commercial and noncommercial rules of customary international law so regularly that Justice Gray provoked no dissent when he wrote: "International law is part of our law, and must be ascertained and administered by the courts of justice of appropriate jurisdiction, as often as questions of right depending upon it are duly presented for their determination."36

There matters stood until Erie, in which Justice Brandeis famously invoked federalism concerns to pronounce that "[ $t]$ here is no federal general common law."37 Curiously, Bradley and Goldsmith read Erie as effecting a near complete ouster of federal courts from their traditional role in construing customary international law norms. But nothing in Justice Brandeis's opinion suggests that he intended to unseat more than a century of settled law on that question.

Erie held that the grant of diversity jurisdiction, standing alone, did not authorize the federal courts to make a general federal common law of tort. ${ }^{38}$ But customary international law differs from the state tort law at issue in Erie in at least three crucial respects. First, Justice Brandeis claimed, the federal courts lack power to fashion common law tort rules in part because "Congress has no power to declare substantive rules of common law applicable in a [s]tate."39 But given both Congress's enumerated authority to define and punish offenses against the law of nations and its affirmative exercise of that power in a range of statutes, no one could similarly claim that federal courts lacked power to make federal common law rules with respect to international law. 40

Second, as Justice Harlan later noted, Erie required that state law be the governing substantive law in diversity cases because "the scheme of our Constitution envisions an allocation of law-making functions between state and federal legislative processes which is undercut if the federal judiciary can make substantive law affecting state affairs beyond the bounds of congressional legislative powers in this regard."41 But with respect to international and foreign affairs law, the Constitution envisions no similar role for state legislative or judicial process. Federal judicial determination of most questions of custom-

\footnotetext{
35 See id. at 8-12.

36 The Paquete Habana, 175 U.S. 677, 700 (1900). The quotation from The Paquete Habana is almost identical to language from another opinion also authored by Justice Gray. See Hilton v. Guyot, I59 U.S. II3, I63 (1895).

37 Erie R.R. Co. v. Tompkins, 304 U.S. 64,78 (1938).

38 See id.

39 Id. at 78 (emphasis added).

40 For examples of statutes enacted pursuant to this constitutional provision, see Alien Tort Claims Act, 28 U.S.C. \& I350 (1994); Piracy Act, Act of Apr. 30, I790, ch. 9, § 8, I Stat. I12, Ir314; and Piracy Act of $1790, \S 28$, I Stat. I I8, criminalizing assaults upon ambassadors.

41 Hanna v. Plumer, 380 U.S. 460, 474-75 (1965) (Harlan, J., concurring) (emphasis added).
} 
ary international law transpires not in a zone of core state concerns, such as state tort law, but in a foreign affairs area in which the Tenth Amendment has reserved little or no power to the states. It was precisely to preserve the federal common lawmaking power of the federal courts in such areas that Justice Brandeis acknowledged - on the very same day that Erie was decided - that federal judges may continue to make specialized federal common law regarding issues of uniquely federal concern. ${ }^{42}$

Third, to treat determinations of customary international law as questions of state law would have rendered both state court and federal diversity rulings effectively unreviewable by the U.S. Supreme Court. Such unreviewability would have raised the specter that multiple variants of the same international law rule could proliferate among the several states. ${ }^{43}$

Writing only one year after Erie, Professor (later World Court Judge) Philip Jessup noted these three problems in arguing that "the holding of th[at] case has no direct application to international law":44

If the dictum of Mr. Justice Brandeis in the Tompkins case is to be applied broadly, it would follow that hereafter a state court's determination of a rule of international law would be a finding regarding the law of the state and would not be reviewed by the Supreme Court of the United States.

.... [A]ny attempt to extend the doctrine of the Tompkins case to international law should [thus] be repudiated by the Supreme Court. $\mathrm{Mr}$. Justice Brandeis was surely not thinking of international law when he wrote his dictum. Any question of applying international law in our courts involves the foreign relations of the United States and can thus be

42 See Hinderlider v. La Plata River \& Cherry Creek Ditch Co., 304 U.S. 92, 1 10 (1938) (stating that the issue of interstate water apportionment "is a question of 'federal common law' upon which neither the statutes nor the decisions of either State can be conclusive $)$. Significantly, in deciding the interstate apportionment issue before the Court in Hinderlider, Justice Brandeis cited two earlier judicial interpretations of customary international law. See id. at ro6 (quoting Poole v. Fleeger, 36 U.S. (II Pet.) I85, 209 (1837) (explaining that "the general right of sovereignty, belonging to independent nations, to establish and fix the disputed boundaries between their respective territories .... is a doctrine universally recognized in the law and practice of nations" and equally belongs to the states of the Union)); id. at I ro (citing Kansas v. Colorado, 206 U.S. 46, 97 (1907) ("Sitting, as it were, as an international, as well as a domestic, tribunal, we apply Federal law, state law, and international law, as the exigencies of the particular case may demand." (quoting Kansas v. Colorado, I85 U.S. 125, 146-47 (1902)) (internal quotation marks omitted))).

43 In Erie, Justice Brandeis had assailed Swift for "attempting to promote uniformity of law throughout the United States [and thus] ... prevent[ing] uniformity in the administration of the law of the [s]tate." Erie, 304 U.S. at 75. But if customary international law were treated as part of the new specialized federal common law, which is both binding on state and federal courts and subject to Supreme Court review, the uniformity of international legal rules could be maintained both throughout the United States and within the individual states. Cf. New York Life Ins. Co. v. Hendren, 92 U.S. 286, 287-88 (I875) (Bradley, J., dissenting) (warning of the dangers if the rights and responsibilities of U.S. citizens under the laws of war were not governed by federal law subject to Supreme Court review).

44 Philip C. Jessup, The Doctrine of Erie Railroad v. Tompkins Applied to International Law, 33 AM. J. INT'L L. 740, 741-43 (r939). 
brought within a federal power. ... The several states of the Union are entities unknown to international law. It would be as unsound as it would be unwise to make our state courts our ultimate authority for pronouncing the rules of international law. ${ }^{45}$

More than a quarter century would pass before the Supreme Court clarified whether customary international law rules should be characterized as state or federal law. ${ }^{46}$ In I964, the Supreme Court took up each of Jessup's concerns in Sabbatino. First, Justice Harlan, writing for an 8-I majority, did not shy away from interpreting questions of customary international law (which, if Bradley and Goldsmith were right, would have raised no substantial federal question worthy of Supreme Court review). ${ }^{47}$ To the contrary, the Court construed customary international law to determine that international law neither compelled nor required application of the act of state doctrine. ${ }^{48}$

Second, Justice Harlan recognized Jessup's distinction between cases that fall within zones of state and federal power. Given the mischief that would ensue if each state could formulate its own act of state rule, ${ }^{49}$ Justice Harlan concluded, any "issue concerned with a basic choice regarding the competence and function of the Judiciary and the National Executive in ordering our relationships with other mem-

45 Id. at 74I-43 (emphasis added).

46 Nine years after Jessup's article appeared, the Second Circuit decided Bergman v. De Sieyes, 170 F.2d 360 (2d Cir. I948), which followed a New York state court interpretation granting diplomatic immunity from civil process in a diversity action. Judge Hand, writing for the court, did not foreclose the possibility that "an avowed refusal to accept a well-established doctrine of international law, or a plain misapprehension of it" would present a federal question. Id. at 36r. Hand's own law clerk, Louis Henkin, characterizes Bergman as one of Hand's "rare mistakes" for failing to address Jessup's Erie concerns. LOUIS HENKIN, FOREIGN AFFAIRS AND THE UNITED STATES ConSTITUTION 4 IO n.2 I (2d ed. I996); see id. at 5 Io n.I9. Writing two years before the Supreme Court's decision in Sabbatino, Covey Oliver, who later became a judge on the International Court of Justice, similarly noted the tension between Bergman and Jessup's I939 article, and presciently predicted that "before the problem is finally settled Jessup's views of I939 will prevail." Covey Oliver, Philip C. Jessup's Continuing Contribution to International Law, 62 COLUM. L. REV. I132, Ir35 (I962).

Although Bradley and Goldsmith give significance to the Second Circuit's isolated ruling in Bergman, see Bradley \& Goldsmith, Customary International Law, supra note $\mathrm{II}$, at 828 \& $\mathrm{n} .75$, 834, that ruling now has little precedential weight, having been overruled sub silentio by the Supreme Court's decision in Sabbatino. Since Sabbatino, no federal court has cited, much less followed, Bergman. Likewise, the New York Court of Appeals has cited it only in a case in which the court ultimately followed the federal executive branch's amicus brief, which had asserted that customary international law is federal law after Sabbatino. See Republic of Argentina v. City of New York, 250 N.E.2d 698, 701 (N.Y. 1969); Neuman, supra note 17 , at 377 .

47 Nor did Justice White's powerful dissent anywhere challenge the majority's conclusion that federal law governed. See Banco Nacional de Cuba v. Sabbatino, 376 U.S. 398, 450-56 (I964) (White, J., dissenting).

48 See Sabbatino, 376 U.S. at 42 I-24.

49 See id. at 424 ("If ... the state courts are left free to formulate their own [act of state] rules, the purposes behind the doctrine could be as effectively undermined as if there had been no federal pronouncement on the subject."). 
bers of the international community must be treated exclusively as an aspect of federal law."so

Third and finally, the Court cited with approval Judge Jessup's recognition of "the potential dangers were Erie extended to legal problems affecting international relations." ${ }^{11}$ The Court noted Jessup's concern for maintaining national uniformity in interpretation of legal rules, and his "caution! that rules of international law should not be left to divergent and perhaps parochial state interpretations."152 Jessup's "basic rationale," the Sabbatino Court concluded, "is equally applicable to the act of state doctrine."

The most plausible reading of this language is that the Sabbatino Court simply confirmed Jessup's understanding that "rules of international law should not be left to divergent and ... parochial state interpretations." ${ }^{154}$ A fortiori, the same reasoning must be "equally applicable" to interpretation of the act of state doctrine, which the Court had not found to be compelled by customary international law. ${ }^{55}$ Far from denying the appropriateness of federal courts' making federal common law rules based on their interpretation of international law, Justice Harlan declared it "apparent that the greater the degree of codification or consensus concerning a particular area of international law, the more appropriate it is for the judiciary to render decisions regarding it, since the courts can then focus on the application of an agreed principle to circumstances of fact." 56

In the decades since Sabbatino, the Supreme Court has routinely held that a "few areas, involving 'uniquely federal interests,' are so committed by the Constitution and laws of the United States to federal control that state law is pre-empted and replaced, where necessary, by federal law of a content prescribed (absent explicit statutory directive) by the courts - so-called 'federal common law.'"57 The Court has

\footnotetext{
50 Id. at 425 .

51 Id.

$52 I d$.

53 Id. (emphasis added).

54 Id.

55 Id. This point becomes even clearer when one reads this language in the context of the full paragraph:

However, we are constrained to make it clear that an issue concerned with a basic choice regarding the competence and function of the Judiciary and the National Executive in ordering our relationships with other members of the international community must be treated exclusively as an aspect of federal law. It seems fair to assume that the Court did not have rules like the act of state doctrine in mind when it decided Erie R.R. Co. v. Tompkins. Soon thereafter, Professor Philip C. Jessup, now a judge of the International Court of Justice, recognized the potential dangers were Erie extended to legal problems affecting international relations. He cautioned that rules of international law should not be left to divergent and perhaps parochial state interpretations. His basic rationale is equally applicable to the act of state doctrine.

Id. (emphasis added) (footnotes omitted).

56 Id. at 428 (emphasis added).

57 Boyle v. United Techs. Corp., 487 U.S. 500, 504 (1988) (citation omitted).
} 
specifically found such a "distinctive federal interest in ... 'the exterior relation of this whole nation with other nations and governments." "'58

The proper reading of this doctrine, in my view, is that even after Erie and Sabbatino, federal courts retain legitimate authority to incorporate bona fide rules of customary international law into federal common law. This judicial authority inheres not just in the distinct federal interest in foreign relations, but also in the explicit grant of authority in Article I, Section 8, Clause Io of the Constitution to define and fashion federal rules with regard to the law of nations, various other constitutional provisions, ${ }^{59}$ and particular federal statutes. ${ }^{60}$ Once customary norms have sufficiently crystallized, courts should presumptively incorporate them into federal common law, unless the norms have been ousted as law for the United States by contrary federal directives. ${ }^{61}$

58 Id. at 508 n.4 (quoting Hines v. Davidowitz, 3I2 U.S. 52, 66 (I94I) (quoting Henderson v. Wickham, 92 U.S. 259, 273 (I876))) (internal quotation marks omitted).

59 See U.S. CoNST. art. III, \& 2 ("[The federal] judicial Power shall extend to all Cases, in Law and Equity, arising under this Constitution, the Laws of the United States, and Treaties made, or which shall be made, under their Authority," as well as to various cases involving ambassadors and controversies with "foreign States, Citizens or Subjects."); id. art. II, \$\$ 2-3 (vesting in the President, a federal entity, certain foreign affairs powers, and directing the President to "take Care that the Laws be faithfully executed," including, presumably, customary international law); $i d$. art. VI, cl. 2 ("[T]he Laws of the United States," which presumptively include bona fide rules of customary international law, "shall be the supreme Law of the Land; and the Judges in every State shall be bound thereby."). With respect to rules affecting foreign commerce, the Foreign Commerce Clause, $i d$. art. I, $\S 8, \mathrm{cl}$. 3 , also provides a grant of constitutional authority sufficiently capacious to bring customary international law rules developed in the commercial area within the federal lawmaking power. Cf. Sabbatino, 376 U.S. at 427 n.25 (citing many of these same constitutional provisions as "reflecting a concern for uniformity in this country's dealings with foreign nations and indicating a desire to give matters of international significance to the jurisdiction of federal institutions"). For a discussion of the interaction among these provisions, see generally Harold Hongju Koh, The National Security Constitution: Sharing Power After TFIE IRAN-CONTRA AFFATR 67-77 (I990).

60 Specific federal statutes, such as the ATCA, 28 U.S.C. $\$$ I350 (I994), and the Foreign Sovereign Immunities Act, 28 U.S.C. $\$ \S 1602-16$ I ( 1976 ), expressly delegate to the federal courts authority to derive federal common law rules from established norms of customary international law. See 28 U.S.C. $\$ 1605(a)(3)$ (I994) (abrogating foreign sovereign immunity in any case in which, inter alia, "rights in property taken in violation of international law are in issue"). Under each of these statutes, a "national body of federal-court-built law has been held to have been contemplated" by the statute, in the same way that the Court in Textile Workers Union v. Lincoln Mills, 353 U.S. 448, 456-57 (1957), held that such a body of law was contemplated by section 3 or of the Labor Management Relations Act of I947, ch. I20, 6I Stat. 136, I56-57 (1947) (codified as amended at 29 U.S.C. § I85 (I994)). Sabbatino, 376 U.S. at 426; see Koh, supra note 30 , at 2368 n.II8.

61 For example, contrary norms embodied in the Constitution, federal treaties or statutes, or controlling and valid presidential acts may supersede the application of customary international law rules as law for the United States. My approach differs from Professor Henkin's, inasmuch as I believe that customary international law is federal common law (not simply "like federal common law"). Compare Henkin, supra note 30 , at $156 \mathrm{I}-65$, with Koh, supra note 30 , at 2368 n.II8, 2386. As I understand it, federal judges exercise post-Erie federal common lawmaking authority to incorporate crystallized rules of customary international law into U.S. federal law, 
Applying this authority in First National City Bank v. Banco Para el Comercio Exterior de Cuba (Bancec), 62 Justice O'Connor found "the principles governing this case are common to both international law and federal common law."63 Similarly, in a string of decisions determining the legal status of submerged offshore areas, the Court has applied customary international law rules to guide its interpretation of federal statutory and treaty provisions. ${ }^{64}$ Moreover, both the Supreme Court and the lower federal courts have regularly looked to customary international law rules when applying the felicitously named "Charming Betsy" principle, a canon of statutory construction that directs that "an act of [C]ongress ought never to be construed to violate the law of

which are in turn perennially subject to modification by political branch action. One need not enter further into the substantial scholarly debate that has raged over whether the President may or may not violate customary international law on the President's own authority to notice that none of the participants in that debate subscribe to Bradley and Goldsmith's view regarding the domestic status of customary international law. See, e.g., Thimble, supra note r6; Agora, May the President Violate Customary International Law?, 80 AM. J. INT'L L. 913 (1986) (hereinafter Agora, Customary International Law I] (essays by Jonathan I. Charney, Michael J. Glennon, and Louis Henkin); Agora, May the President Violate Customary International Law? (Cont'd), 8I AM. J. INT'L L. 37 I (1987) [hereinafter Agora, Customary International Law II] (essays by Frederic L. Kirgis, Jr., Anthony D'Amato, and Jordan J. Paust).

62462 U.S. 6 II ( 1983$)$.

63 Id. at 623. More recently, in Hartford Fire Insurance Co. v. California, 509 U.S. 764 (1993), Justice Scalia, writing for four dissenting Justices, found that "the practice of using international law to limit the extraterritorial reach of statutes is firmly established in our jurisprudence," and thus should have barred the assertion of extraterritorial jurisdiction in that case. Id. at 818 (Scalia, J., dissenting). Justice Souter's majority opinion did not expressly address the international law question. For analysis of these opinions, see generally William S. Dodge, Extraterritoriality and Conflict-of-Lawes Theory: An Argument for Judicial Unilateralism, 39 HARV. INT'L L.J. Ior, I35-43 (1998).

64 During the past 40 years, the Supreme Court has repeatedly looked to customary international law to aid its determinations regarding title to lands and islands in "historic waters" off particular state coast lines. See United States v. Alaska, II7 S. Ct. 1888, 1897-99 (1997) (holding under international law that the United States had properly constructed baselines in part of the Beaufort Sea); United States v. Alaska, 503 U.S. 569,588 \& n.IO (1992) (considering arguments based on the baseline provisions of the U.N. Convention on the Law of the Sea, which the United States asserted as customary international law, to determine an executive official's statutory authority to condition a permit); United States v. Louisiana (The Alabama and Mississippi Boundary Case), 470 U.S. 93, I06-07 (1985) (applying customary international law to define the term "historic bay" in the 1958 Territorial Sea Convention); United States v. Maine (The Rhode Island and New York Boundary Case), 469 U.S. 504, 526 (1985) (holding that Long Island and Block Island Sounds constituted a "juridical bay," and that their waters were therefore internal state waters); United States v. Alaska, 422 U.S. I84, 202-04 (1975) (applying similar reasoning to determine that Alaska's Cook Inlet did not meet the criteria for "historic waters"); United States v. Louisiana, 394 U.S. II, 22 (1969) (applying "generally accepted principles of international law" to deny Louisiana's claim of historic title to certain coastal waters); United States v. California, 38I U.S. I39, $164-65$ ( 1965 ) (construing the Submerged Lands Act in light of, inter alia, customary international law); United States v. Louisiana, 363 U.S. I, 66-82 (1960) (holding that Louisiana, Alabama, and Mississippi were not entitled to a historic seaward boundary greater than three geographical miles from their coastlines). Needless to say, none of these cases could have been uncontroversially decided had the rules of decision been subject to the state law of one of the interested jurisdictions. Cf. Sabbatino, 376 U.S. at 427 (comparing "[ $t$ ]he considerations supporting exclusion of state authority here" to those in an early submerged lands case). 
nations, if any other possible construction remains."65 Finally, in addition to their numerous rulings under the Alien Tort Claims Act (ATCA), ${ }^{66}$ lower federal courts have determined customary international rules to be federal common law with regard to such diverse mat-

65 Murray v. The Schooner Charming Betsy, 6 U.S. (2 Cranch) 64, II8 (I804) (Marshall, C.J.). These decisions have construed federal statutes in light of both treaties and customary international law rules, without drawing sharp distinctions between the domestic legal status of each. For examples of decisions construing federal statutes in light of treaties, see Trans World Airlines, Inc. v. Franklin Mint Corp., 466 U.S. 243, 252 (1984); Weinberger v. Rossi, 456 U.S. 25, 32 (I982); and United States v. Palestine Liberation Org., 695 F. Supp. 1456 , 1465 (S.D.N.Y. I988). Numerous decisions have construed federal statutes in light of customary international law, a practice that would make little sense if customary international law were state law. See, e.g., McCulloch v. Sociedad Nacional de Marineros de Honduras, 372 U.S. Io, 21 (rg63) (holding that a proposed construction of the National Labor Relations Act would have been contrary to a "well-established rule of international law"); Lauritzen v. Larsen, 345 U.S. 57 I, 578 (1953) (holding that the Jones Act should not be construed to apply to extraterritorial acts of foreigners done on a foreign ship); Finzer v. Barry, 798 F.2d 1450, I459 (D.C. Cir. 1986) (Bork, J.), aff'd in part and rev'd in part sub nom., Boos v. Barry, 485 U.S. 312 (I988) ("[W]e are asked to review a statute which both Congress and successive Presidents have declared to be necessary to fulfill our obligations under ... customary international law ...."); Commodity Futures Trading Comm'n v. Nahas, 738 F.2d 487, 493-94 (D.C. Cir. I984) (refusing to enforce extraterritorial service of agency subpoena on grounds that broad reading of the statute would violate customary rules regarding extraterritorial application of enforcement jurisdiction); FTC v. Compagnie de Saint-Gobain-Pont-à-Mousson, 636 F.2d I300, I304, I323 n.r30 (D.C. Cir. I980) (same); United States v. Marino-Garcia, 679 F.2d I373, I379-80 (I Ith Cir. I982), cert. denied, 459 U.S. I I I4 (I983) (stating that jurisdiction cannot "exceed the bounds of international law"); United States v. James-Robinson, 5 I 5 F. Supp. I340, I34647 (S.D. Fla. I98I) (same with respect to the Marijuana on the High Seas Act, PUB. L. No. 96350, 94 Stat. II59 (1980)). See generally Ralph G. Steinhardt, The Role of International Law As a Canon of Domestic Statutory Construction, 43 VAND. L. REV. 1 IO3 (I9go) (discussing many of these cases).

66 See Bradley \& Goldsmith, Customary International Law, supra note II, at $8 \mathrm{I} 7 \mathrm{n} .3$ (citing cases); see generally Clyde H. Crockett, The Role of Federal Common Law in Alien Tort Statute Cases, 14 B.C. INT'L \& COMP. L. REV. 29 (Ig9I) (discussing cases). 
ters as expropriation, ${ }^{67}$ treaty interpretation, 68 extradition, 69 official immunity, ${ }^{70}$ and treatment of prisoners ${ }^{71}$ and detainees. ${ }^{72}$

These decisions amply illustrate the broader incoherence of the Bradley and Goldsmith approach. For the capacity of the federal courts to incorporate customary international law into federal law unless ousted by contrary federal directive - is absolutely critical to maintaining the coherence of federal law in areas of international concern. With certain exceptions, placing all international law on a federal, subconstitutional plane gives customary international law a lexical comparability with treaties and statutes, which are superior to state law under the Supremacy Clause. ${ }^{73}$ Federal court decisions in the international field thus frequently rely on a blend of federal statutory and treaty interpretation, customary international law, and federal common law to fashion federal rules of decision that are often later formalized in new treaties or statutes.

In the Bancec case, for example, the Court derived a federal rule regarding the piercing of the corporate veil of foreign government entities from federal common law rules, as "necessarily informed both by international law principles and by articulated congressional policies."74 Similarly, in Hartford Fire Insurance Co. v. California, ${ }^{75}$ five Justices evaluated the extraterritorial reach of the federal antitrust law

67 See, e.g., Banco Nacional de Cuba v. Chase Manhattan Bank, 658 F.2d 875, 89I-93 (2d Cir. I98I) (finding that under customary international law, Cuba was obligated to pay either "appropriate" or "full" compensation for a taking).

68 See, e.g., Jhirad v. Ferrandina, 355 F. Supp. II55, II59 (S.D.N.Y. 1973) (applying international law rules to determine whether an extradition treaty still validly existed between India and the United States).

69 See, e.g., Fiocconi v. Attorney General, 462 F.2d 475, 479-80 \& n.8 (2d Cir. 1972) (Friendly, C.J.) (noting that rule of specialty in extradition "partakes of both" domestic and international law, and applying it under Sabbatino as "a rule of what we would now call United States foreign relations law devised by the courts to implement the [extradition] treaty").

70 See, e.g., United States v. Enger, 472 F. Supp. 490, 540-4I (D.N.J. 1978) (construing the congressional intent underlying the term "goods or chattels" of a diplomat by reference to sources of customary international law).

71 See, e.g., Lareau v. Manson, 507 F. Supp. II77, II88 n.9 (D. Conn. I980) (Cabranes, J.), aff'd in part, 65I F.2d 96 (2d Cir. I98I) (considering U.N. Standard Minimum Rules for the Treatment of Prisoners as "expressions of the obligations ... of the member states of the United Nations, and as part of the body of international law (including customary international law) concerning human rights") (citation omitted).

72 See, e.g., Fernandez v. Wilkinson, 505 F. Supp. 787, 795-98 (D. Kan. 1980), aff'd on other grounds sub nom., Rodriguez-Fernandez v. Wilkinson, 654 F.2d 1382 (roth Cir. 1981).

73 See U.S. CoNST. art. VI, cl. 2.

74 First Nat'l City Bank v. Banco Para el Comercio Exterior de Cuba, 462 U.S. 6rI, 623 (1983). Similarly, in the submerged land cases, the Court construed federal legislation respecting ownership of submerged lands in light of complementary rules in treaties regarding the territorial sea and the customary international law of the sea. See cases cited supra note 64 .

75509 U.S. 764 (I993). 
in light of the federal common law principle of comity, while four others construed the statute in light of customary international law. ${ }^{76}$

If all of these rules are federal (as the prevailing view suggests), then the uniquely federal area of foreign relations operates on an entirely federal plane, with statutes and treaties providing the positive law framework and federal common law rules (interpreting statutes, treaties, and customary international law) filling the interstices. As Congress and the executive branch exercise their supervisory powers, federal common law doctrine evolves and mutates to reflect the changing face of international law.

Take, for example, the federal doctrine of foreign sovereign immunity, which originated in the customary international law doctrine of absolute foreign sovereign immunity. Over time, the Supreme Court incorporated that decision into United States law and melded it with a federal common law doctrine of judicial deference to federal executive suggestions of immunity. ${ }^{77}$ Eventually, executive policy brought U.S. practice into line with the emerging customary international law doctrine of restrictive sovereign immunity, ${ }^{78}$ and Congress codified the new doctrine in the Foreign Sovereign Immunities Act (FSIA), ${ }^{79}$ whose gaps federal courts have subsequently filled by declaring rules of federal common law. ${ }^{80}$ In short, rules that originate in customary interna-

76 Compare id. at 794-99 (Souter, J., concurring) (analyzing the issue as governed by the federal common law principle of comity), with id. at 8I 2-22 (Scalia, J., dissenting) (arguing that jurisdictional reach of the antitrust statute should instead have been construed in light of customary international law).

77 See Schooner Exchange v. McFaddon, II U.S. (7 Cranch) II6, I36 (I8I2) (declaring the rule of absolute foreign sovereign immunity). For cases illustrating the doctrine of executive suggestion, see, for example, Republic of Mexico v. Hoffman, 324 U.S. 30 (I945); Ex parte Peru, 3 I8 U.S. 578 (I943); and Berizgi Bros. Co. v. S.S. Pesaro, 27 I U.S. 562 (I926). For a description of the evolution of the U.S. law of foreign sovereign immunity, see generally HENRY J. STEINER, Detlev F. VaGts \& HaRold HoNGJu KOH, TransNational LeGal. Problems 753-8Ig (4th ed. 1994).

78 See Changed Policy Concerning the Granting of Sovereign Immunity to Foreign Governments ("Tate Letter"), May 19, 1952, DEP'T ST. BULL., June 23, 1952, at 984, 985 (concluding, after an extensive survey of foreign State practice, that "the widespread and increasing practice on the part of governments of engaging in commercial activities makes necessary" a shift to an executive policy of restrictive foreign sovereign immunity).

7928 U.S.C. $\$ \S 1330,1602-16$ I I (1994). The FSIA, in turn, became but one piece of a worldwide movement to codify the law of restrictive foreign sovereign immunity through national legislation that soon included state immunity acts in the United Kingdom, Singapore, South Africa, Pakistan, Canada, and Australia, among others countries. See generally U.N. MATERIALS ON THE JURISDictional IMmUNities OF StATES AND Their PROPERTy, U.N. Doc. ST/LEG/SER.B/20, U.N. Sales No. E/F.8I.V.Io (I982) (including national legislation from numerous countries). These national statutes inspired a multilateral codification movement, now led by the International Law Commission's Draft Convention on Jurisdictional Immunities of States and Their Property. See generally Virginia Morris, The International Law Commission's Draft Convention on the Jurisdictional Immunities of States and Their Property, I7 DENV. J. INT'L L. \& POL'Y 395 (I989) (discussing the draft convention).

80 See, e.g., Liu v. Republic of China, 892 F.2d I4I9, I425-26 (9th Cir. I989); Harris v. Polskie Linie Lotnicze, 820 F.2d 1000, $1003-04$ (9th Cir. 1987) (applying federal common law to create a 
tional law are regularly determined by United States courts and incorporated into federal common law, then updated by executive policy as customary law evolves, and codified in federal statutes whose interstices are filled through federal common lawmaking.

Bradley and Goldsmith would disrupt this dynamic framework by creating two rigid tiers of international law within the United States legal system: a federal tier for ratified treaties, and a state tier for what they deem to be lesser, non-positive customary law. ${ }^{81}$ Under their scenario, a treaty that is not ratified, but that nevertheless announces important customary international law rules - for example, the Vienna Convention on the Law of Treaties ${ }^{82}$ or the United Nations Convention on the Law of the Sea ${ }^{83}$ - need not be applied or respected by state courts or legislatures unless expressly executed by a statute or order emanating from the federal political branches. ${ }^{84}$ Under this reasoning, the fifty states of the Union had no domestic legal obligation to obey customary norms against genocide during the period from December 1948, when the United States first signed the Genocide Convention, until November. $x 988$, when the United States finally ratified that treaty and executed it as domestic federal law. ${ }^{85}$

FSIA choice of law rule); Mashayekhi v. Iran, 5I5 F. Supp. 4I, 43 (D.D.C. 198I) (applying federal common law to construe the immunity provisions of a bilateral treaty in light of FSIA).

81 Indeed, one might read Bradley and Goldsmith as creating yet a third, subordinate customary international law tier, whose rules state courts and legislatures may selectively incorporate, or refuse to incorporate, at their discretion. See Bradley \& Goldsmith, Current Illegitimacy, supra note 15 , at $349-50$.

82 Vienna Convention on the Law of Treaties, opened for signature May 23, 1969, S. ExEC. Doc. L, 92-I (I97I); see also I RESTATEMENT (THIRD) OF THE FOREIGN RELATIONS LAW OF THE UNITED STATES I45 (I986) [hereinafter RESTATEMENT (THIRD)] ("This Restatement accepts the Vienna Convention as, in general, constituting a codification of the customary international law governing international agreements, and therefore as foreign relations law of the United States even though the United States has not adhered to the Convention.").

83 United Nations Convention on the Law of the Sea, opened for signature Dec. Io, I982, 2 I I.L.M. 126I. Although the United States objected to the deep seabed mining provisions of the I 982 Convention on the Law of the Sea, it accepted large parts as customary international law. See United States Oceans Policy, I9 WeEkLy CoMP. Pres. Doc. 383 (Mar. 14, 1983). At this writing, I20 nations have ratified the 1982 Convention, and the United States has finally declared its intent to seek formal ratification. See Testimony February 10, 1998 Madeleine K. Albright Secretary Department of State Senate Foreign Relations FYg9 Foreign Policy Budget Request, Federal Document Clearnjghouse Congressional Testmony, Feb. 1o, 1998, available in LEXIS, News Library, Curnws File.

84 Thus, rather than adopting the prevailing view of presumptive incorporation through judicial action, Bradley and Goldsmith would adopt the opposite rule of presumptive ouster absent express political incorporation. As Professor Lessig notes, under Bradley and Goldsmith's highly formal, "strictly positivistic view, the only law is domestic law, and the only domestic law is statute or constitution based; so before international law gets incorporated into a domestic regime, a statute must ratify it." Lessig, supra note 17 , at 18 ro.

85 See Genocide Convention Implementation Act of 1987 , Pub. L. No. 100-606, 102 Stat. 3045 (codified in I8 U.S.C. $\S \S$ IogI-I093 (Ig94)) (implementing the Genocide Convention on Nov. 5, I988); Recent Actions Regarding Treaties to Which the United States is a Party, 28 I.L.M. 786 (1989) (giving notice that the United States deposited notice of ratification on Nov. 25, 1988). 
Were Bradley and Goldsmith's position the law, we would expect to see proliferation of varying state rules of customary international law, or even the total exclusion of such norms from state law. Yet the Constitution created the institutions of federal government precisely to avoid such balkanization of foreign policy and international affairs. In The Federalist No. 8o, Alexander Hamilton expressed concern that the United States might be held internationally responsible for "an unjust sentence against a foreigner" issued by a state court. ${ }^{86}$ As founders of a fledgling nation broadly subject to the law. of nations, the Framers feared that a state court's denial of international justice might inspire the alien's nation to make war on the United States. ${ }^{87}$ To avoid that scenario, Hamilton outlined a distinction "between cases arising upon treaties and the laws of nations and those which may stand merely on the footing of the municipal law."88 "The former kind," he suggested, "may be supposed proper for the federal jurisdiction, the latter for that of the [s]tates." 89

History and doctrine thus suggest that the so-called "modern position" extends at least as far back as Alexander Hamilton. Far from being novel, the "modern position" is actually a long-accepted, traditional reading of the federal courts' function. Both before and after Erie, the federal courts issued rulings construing the law of nations. Erie never intended to alter or disrupt that practice, which has continued as the "new" federal common law. The Supreme Court and the lower courts endorsed this view of Erie in Sabbatino and in myriad subsequent decisions. The only question, then, is whether countervailing constitutional concerns regarding separation of powers, federalism, or "democracy" should now force reconsideration of what should correctly be termed the "traditional position."

\section{Separation of Powers}

If customary international law is federal law, Bradley and Goldsmith suggest, "judicial enforcement would seem to raise special sepa-

86 The Federalist No. 80, at 477 (Alexander Hamilton) (Clinton Rossiter ed., 1961). In the famous Marbois Incident of 1784 , an alien who assaulted a foreign diplomat was tried criminally in a state court, demonstrating the vulnerability of the federal government when international law claims are heard before state judges. See Kenneth C. Randall, Federal Jurisdiction Over International Law Claims: Inquiries into the Alien Tort Statute, I8 N.Y.U. J. INT'L L. \& PoL. I, 24-28 (1985) (discussing the Marbois Incident).

87 See The FederalisT No. 80, supra note 4, at 476-77 (Alexander Hamilton) ("[T]t is at least problematical whether an unjust sentence against a foreigner ... would not, if unredressed, be an aggression upon his sovereign, as well as one which violated the stipulations in a treaty or the general law of nations."); $c f$. Tel-Oren v. Libyan Arab Republic, 726 F.2d 774, 8r3-I4 (D.C. Cir. 1984) (Bork, J., concurring) (acknowledging a class of federal common law torts that constituted "the kinds of offenses for which Congress wished to provide tort jurisdiction for suits by aliens in order to avoid conflicts with other nations") (emphasis added).

88 THE FEDERALIST No. 80, supra note 4 , at 476 (Alexander Hamilton) (emphasis added).

89 Id. 
ration-of-powers concerns, since the President needs flexibility in representing the United States on the international plane and plays a central role in representing the U.S. position concerning the content of [customary international law]."90 But if these separation of powers concerns are serious, they must be of very recent vintage. The century-old case of The Paquete Habana ${ }^{91}$ is but one example of a routine Supreme Court decision that enforced a rule of customary international law against an executive official, without a trace of separation of powers concerns. ${ }^{92}$

Sabbatino repeatedly emphasized the "proper distribution of functions between the judicial and political branches of the [federal] Government on matters bearing upon foreign affairs."93 But in the next breath, Sabbatino also cautioned that "[t]his decision in no way intimates that the courts of this country are broadly foreclosed from considering questions of international law."94 "[T]he greater the degree of codification or consensus concerning a particular area of international law," the Court declared, "the more appropriate it is for the judiciary to render decisions regarding it . . .."95

Thus, when customary international norms are well-defined, the executive branch has regularly urged the federal courts to determine such rules as matters of federal law. ${ }^{96}$ In Filartiga $v$. Pena-Irala, ${ }^{97}$ the target of much of Bradley and Goldsmith's critique, the Justice and State Departments together urged the Second Circuit to construe the

90 Bradley \& Goldsmith, Current Illegitimacy, supra note I5, at 352.

91 I75 U.S. 677 (1900).

92 In The Paquete Habana, the United States Navy condemned as prize of war fishing vessels owned by Spanish citizens. See id. at 678-79. The owners sought recovery of the vessels, asserting that customary international law barred the seizure of private fishing vessels as prize. See id. After reviewing customary international law, the Court accepted the owners' interpretation and ordered that they be paid the proceeds from the sale of those vessels. See Scott W. Stucky, The Paquete Habana: A Case History in the Development of Intemational Law, I5 U. BALT. L. REV. I, I4-32 (I985).

93 Banco Nacional de Cuba v. Sabbatino, 376 U.S. 398, 427-28 (1964).

94 Id. at 430 n.34.

95 Id. at 428 (emphasis added).

96 See, e.g., II I988 DigesT OF U.S. PRACTICE, supra note 25, at I58I (quoting Statement of Interest of the United States (Mar. 2I, I988), in Chuidian v. Philippine Nat'l Bank, 734 F. Supp. 4r5 (C.D. Cal. I990) (No. CV 86-2255-RSWL) (urging the district court to determine the immunity of a government official "in accordance with the general principles of sovereign immunity, rather than in accordance with the FSIA")); III I988 DIGEST OF U.S. PRACTICE, supra note 25, at 3439 (quoting Memorandum prepared by U.S. Department of State Office of Legal Adviser (Mar. 29, I988), in United States v. Shakur, 690 F. Supp. I291 (S.D.N.Y. I988) (Nos. 84 Cr. 220-CSH, SSS 82 Cr. 3I2-CSH) (urging district court to find, in accordance with customary international law, that the criminal defendant is not a prisoner of war)); Neuman, supra note 17 , at 377 (discussing the Nixon Administration's amicus brief urging enforcement of the customary international law rule of consular tax immunity in Republic of Argentina $v$. City of New York, 250 N.E.2d 698 (N.Y. I969)).

97630 F.2d 876 (2d Cir. I980). 
international law norms involved under the ATCA. ${ }^{98}$ The Administration explicitly rejected Bradley and Goldsmith's view, citing Sabbatino and The Paquete Habana for the proposition that "[c]ustomary international law is federal law, to be enunciated authoritatively by the federal courts." 99

More recently, in Kadic v. Karadzic, ${ }^{100}$ the Solicitor General and the Legal Adviser of the State Department urged the Second Circuit to vacate and remand the jurisdictional dismissal of an ATCA suit against Bosnian Serb leader Radovan Karadzic. ${ }^{101}$ Far from rejecting what Bradley and Goldsmith call "the open-ended Filartiga approach to the judicial incorporation of CIL into federal law,"102 the Solicitor General called Filartiga "the starting point for the necessary analysis," that is, "a rigorous analysis of a range of factors in order to determine whether an action can be pursued under the Alien Tort Statute for a violation of the law of nations."103 Rather than declaring modern human rights litigation to be "illegitimate," based on the so-called "new" customary international law, the executive branch expressly acknowledged the court's duty to conduct such litigation by "looking to modern conceptions of customary international law."104 In short, nothing in the executive branch's approach to recent human rights cases suggests that federal common law rules of customary international law unconstitutionally intrude upon executive prerogative.

Nor do Bradley and Goldsmith explain how treating customary international law as federal common law unconstitutionally invades the legislative prerogative. As noted above, Article I, Section 8, Clause ro of the Constitution grants Congress express authority to define and punish offenses against the law of nations, a power that it has exercised over the years by enacting a broad range of statutes. ${ }^{105}$ Much of

98 "[S]uch suits unquestionably implicate foreign policy considerations. But not every case or controversy which touches foreign relations lies beyond judicial cognizance. Like many other areas affecting international relations, the protection of fundamental human rights is not committed exclusively to the political branches of government." Memorandum for the United States as Amicus Curiae, Filartiga v. Pena-Irala, 630 F.2d 876 (2d Cir. I980) (No. 79-6090), reprinted in I9 I.L.M. 585,603 (Ig80) (citations omitted).

99 Id. at 606 n.49 (Ig80) (emphasis added).

10070 F.3d 232 (2d Cir. I 995 ).

101 See Brief of United States as Amicus Curiae at 2, Kadic v. Karadzic, 70 F.3d 232 (2d Cir. 1995) (Nos. 94-9035, 94-9069).

102 Bradley \& Goldsmith, Current Illegitimacy, supra note 15 , at 366.

103 Brief of United States at 2, Kadic (Nos. 94-9035, 94-9069). The executive branch suggested that, as long as courts engage in such a rigorous analysis, separation of powers concerns need not arise. See id. at I (finding "no merit to the suggestion ... that the justiciability of these cases is in doubt because of the [political question doctrine or] the theoretical possibility that Karadzic might some day be recognized by the Executive Branch as a head of state ${ }^{\eta}$.

$104 I d$. at 2.

105 See statutes cited supre note 6o. For more recent statutes, see, for example, War Crimes Act, I8 U.S.C.A. § 2441 (Supp. I997); Comprehensive Anti-Apartheid Act of I986, Pub. L. No. 
the federal courts' lawmaking in the human rights area represents statutory gap-filling, particularly with respect to statutes such as the ATCA and the Torture Victim Protection Act (TVPA). ${ }^{106}$ In Filartiga and its progeny, numerous federal courts construed the ATCA to permit aliens to sue foreign officials for acts of torture, summary execution, disappearance, and similar universal crimes committed under color of state law. ${ }^{107}$ After extensive lobbying by human rights groups, in 1992 Congress finally passed the TVPA, which was designed specifically to supplement and complement, not to narrow, the preexisting scope of the ATCA. ${ }^{108}$ The TVPA codified and extended to citizen plaintiffs statutory causes of action for torture and summary execution suffered under the actual or apparent authority, or under color of law, of any foreign nation. ${ }^{109}$ The TVPA's legislative history expressly declared that "[i]nternational human rights cases predictably raise legal issues - such as interpretations of international law - that are matters of Federal common law and within the particular expertise of Federal courts." 110

Bradley and Goldsmith cite no contrary evidence to suggest that Congress viewed such federal common lawmaking as unconstitutionally infringing upon its legislative prerogatives. To the contrary, their initial article conceded that Congress not only has constitutional power to legislate human rights norms into federal law, but "did precisely this with respect to torture cases when it enacted the Torture Victim Protection Act."111 But in their most recent writing, they reverse course, now reading the TVPA to reflect "a broader and unambiguous pattern

99-440, 100 Stat. 1086; and Omnibus Diplomatic Security and Antiterrorism Act of 1986, Pub. L. No. 99-399, 100 Stat. 875 .

106 See Torture Victim Protection Act, Pub. L. No. 102-256, 106 Stat. 73 (1992); supra note 33.

107 See supra note 65.

108 See, e.g., House COMm. ON THE JUdiciary, Torture Victm Protection ACT, H. R.

REP. No. I02-367, pt. I, at 3, 4 (I991), reprinted in 1992 U.S.C.C.A.N. 84, 86. The Report states:

Section I350 [the ATCA] has other important uses and should not be replaced. ... [C]laims based on torture or summary executions do' not exhaust the list of actions that may appropriately be covered [by] section 1350. That statute should remain intact to permit suits based on other norms that already exist or may ripen in the future into rules of customary international law.

Id. (emphasis added); see also Torture Victim Protection Act: Hearings on H.R. 1417 Before the Subcomm. on Human Rights and Int'l Orgs. of the House Comm. on Foreign Affairs, rooth Cong. I (rg88) (remarks of Rep. Yatron, chairman of subcommittee) ("It is not the intent of the Congress to weaken [the Alien Tort Claims Act], but to strengthen and clarify it.").

109 Numerous groups, including the American Bar Association, the Association of the Bar of the City of New York, and the Lawyers Committee for Human Rights, testified before the House, seeking to ensure that enactment of the TVPA would not be interpreted as undercutting the legitimacy of human rights litigation under the ATCA. See Torture Victim Protection Act: Hearings on H.R ${ }_{1417}$ Before the Subcomm. on Human Rights and Int'l Orgs. of the House Comm. on Foreign Affairs, Iooth Cong. I, 7 I-72 (I988).

110 S. REP. No. 102-249, at 6 n.6 (199r) (emphasis added).

111 Bradley \& Goldsmith, Customary Intermational Law, supra note II, at 873. 
of political branch resistance to open-ended incorporation of international human rights norms" into federal law. ${ }^{112}$

In fact, Bradley and Goldsmith's latest position offends legislative prerogatives. After demanding explicit political branch authorization as a precondition to incorporating international law norms, the authors construe two duly enacted statutes in a way that all but negates the political act of incorporation. In the name of judicial restraint, and without any specific evidence of congressional intent, they read the TVPA - the later, complementary statute - to repeal de facto the ATCA - the earlier, broader statute - with respect to all claims other than torture and summary execution (the two causes of action expressly created by the TVPA). ${ }^{113}$ Not only do the authors provide no statutory evidence for such an implicit repealer, ${ }^{114}$ they rely on speculation about the atmosphere surrounding the legislative process to support their narrow reading of the TVPA. ${ }^{115}$

As Ryan Goodman and Derek Jinks have recently demonstrated, Congress designed the TVPA to do far more than this minimal task. ${ }^{116}$ In enacting this statute, Congress expressly intended both to codify and to extend to citizens the Second Circuit's holding in Filartiga. ${ }^{117}$ In so doing, Congress both recognized and approved the federal courts' traditional authority under federal common law to determine whether particular rules have ripened into customary international law. ${ }^{118}$

Ironically, Bradley and Goldsmith's approach creates, rather than alleviates, separation of powers concerns. For after demanding that the political branches enact statutes that domesticate international human rights norms, the authors endorse a judicial approach that

112 Bradley \& Goldsmith, Current Illegitimacy, supra note ${ }_{5}$, at 367 (emphasis added).

113 See id. at 366 ("Congress in the TVPA federalized only prohibitions on torture and extrajudicial killing. Moreover, the TVPA appears in fact to limit the Filartiga approach with respect to these two central and important international law prohibitions.").

114 The Rehnquist Court has repeatedly emphasized the presumption against repeals by implication. See, e.g., Pittsburgh \& Lake Erie R.R. Co. v. Railway Labor Executives' Ass'n, 49I U.S. 490, 5 Io (I989); Traynor v. Turnage, 485 U.S. 535, 55 I (I988); Atchison, Topeka \& Santa Fe Ry. Co. v. Buell, 480 U.S. 557, 566-67 (1987).

115 See Bradley \& Goldsmith, Current Illegitimacy, supra note ${ }_{55}$, at 367 (noting the "years of debate, compromise, and precise drafting" that went into the statute, and concluding that "[i]t is extremely unlikely that the members of Congress who demanded [many legislative] changes and ultimately voted for the TVPA would have assented to the much broader, open-ended, and undefined Filartiga approach.").

116 See Goodman \& Jinks, supre note 17 , at 513-28.

117 See Lafontant v. Aristide, 844 F. Supp. 128, 138 (E.D.N.Y. 1994) ("The TVPA codifies the holding in Filartiga ...."); I37 CONG. REC. Sr378, Sr378 (daily ed. I99I) (remarks of Sen. Specter, principal Senate sponsor) ("This bill would extend protection to U.S. citizens while retaining the current law's protection of aliens.").

118 See House Comm. ON THE Judiciary, TORTURe Victim Protection ACT, H.R. ReP. No. $102-367$, pt. I, at 4 (199I), reprinted in I992 U.S.C.C.A.N. 84,86 (explaining that the ATCA "should remain intact to permit suits based on other norms that already exist or may ripen in the future into rules of customary international law" (emphasis added)). 
would read most of two such statutes off the books. They read an act of Congress specifically denominated for the protection of torture victims as mere lip service toward that end. In the face of express, contrary legislative history, they urge judges to use the political "background against which the legislative history of the TVPA must be read" to eviscerate the statute. ${ }^{119}$ If this is a plea against judicial activism, it is a very curious one indeed.

\section{Federatism}

Bradley and Goldsmith's plea for states' rights strikes an even stranger chord. They argue that the traditional exercise of federal common lawmaking power with regard to customary international rules "portends a dramatic transfer of constitutional authority from the states to the world community and to the federal judiciary."120 But surely, that transfer of authority did not take place recently, at the behest of a few academics, but at the beginning of the Republic, ${ }^{121}$ from the dictates of the Supreme Court, Congress, and the federal executive branch, the primary beneficiary of this trend.

The trend toward federal supremacy in foreign affairs established at the founding accelerated with the Chinese immigration cases of the late nineteenth century. These cases declared Congress's power to control immigration to be exclusive and inherent in the sovereignty of the United States. ${ }^{122}$ Numerous subsequent decisions confirmed the broad range of Congress's exclusive powers under the Foreign Commerce Clause. ${ }^{123}$

Then, in United States v. Curtiss-Wright Export Corp., ${ }^{124}$ the Court suggested that the federal power over foreign affairs never derived from the states. Instead, Justice Sutherland's opinion asserted, that power vested directly "in the federal government as necessary con-

119 Bradley \& Goldsmith, Current Illegitimacy, supra note 15 , at 367 .

120 Bradley \& Goldsmith, Customary International Law, supra note II, at 846 .

121 As Professor Henkin notes, "[bly virtue of independence and statehood, international law became binding on the United States, not on the individual states." Henkin, supra note 3r, at 1556-57; see Richard B. Morris, The Forging of the Union Reconsidered: A Historical Refutation of State Sovereignty over Seabeds, 74 CoLUM. L. REV. 1056, 1074-83 (I974).

122 See, e.g., Louis Henkin, The Constitution and United States Sovereignty: A Century of Chinese Exclusion and Its Progeny, Ioo HARv. L. Rev. 853, 853-63 (1987); Stephen H. Legomsky, Immigration Law and the Principle of Plenary Congressional Power, I984 SUP. CT. REV. 255, 266-67, 288-89 (1985); Stephen H. Legomsky, Ten More Years of Plenary Power: Immigration, Congress, and the Courts, 22 HASTINGs CoNST. L.Q. 925, 925-26 (I995).

123 See, e.g., Itel Containers Int'l Corp. v. Huddelston, 507 U.S. 60, 71-78 (r993); Wardair Canada Inc. v. Florida Dep't of Revenue, 477 U.S. I, 7-r3 (rg86); Japan Line, Ltd. v. County of Los Angeles, 44I U.S. 434, 448 (r979) ("In international relations and with respect to foreign intercourse and trade the people of the United States act through a single government with unified and adequate national power." (citation omitted) (internal quotation marks omitted)).

124299 U.S. 304 (1936). 
comitants of nationality,"125 to be exercised by the President "as the sole organ of the federal government in the field of international relations." 126 The following Term, in United States v. Belmont,127 Justice Sutherland made clear that in the foreign affairs realm, claims of states' rights carry little weight. ${ }^{128}$ "[I]n respect of our foreign relations generally," Justice Sutherland wrote, "state lines disappear. As to such purposes the state of New York does not exist."129 Amid this historical background, Sabbatino provides the judicial piece of the federal supremacy picture. The decision acknowledged the supremacy of not only Congress and the President, but also federal judges' making common law rules in the area of external relations. The Sabbatino Court found such federal common lawmaking to be justified by explicit constitutional grants and the need to maintain national uniformity in areas of uniquely federal interest. 130

Bradley and Goldsmith challenge this orthodoxy with a peripheral attack on the doctrine of "dormant foreign relations preemption,"131 as exemplified by the Supreme Court's decision in Zschernig v. Miller. ${ }^{132}$ In $Z$ schernig, the Court invalidated an Oregon "Iron Curtain" statute as an unconstitutional "intrusion by the [s]tate into the field of foreign affairs."133 Justice Stewart's concurrence made clear that the case fell squarely under Sabbatino's rationale. "[T]he conduct of our foreign affairs," he wrote, "is entrusted under the Constitution to the National Government, not to the probate courts of the several States."134

$Z s c h e r n i g$ has been appropriately criticized for its failure to delineate clearly when a state's decision has such broad international repercussions that it should be deemed specifically preempted. ${ }^{135}$ In the modern era, situations increasingly arise in which state and national governments exercise overlapping authority, the federal government

125 Id. at 318.

126 Id. at 320 . For criticism of the decision, see, for example, $\mathrm{KOH}$, cited above in note 59 , at page 94 .

127 30r U.S. 324 (1937).

128 See id. at $33 \mathrm{I}$.

129 Id. at 33r; see also United States v. Pink, 315 U.S. 203, 233 (1942) ("We repeat that there are limitations on the sovereignty of the States. No State can rewrite our foreign policy to conform to its own domestic policies. Power over external affairs is not shared by the States; it is vested in the national government exclusively.").

130 See supra notes 54-6I and accompanying text.

131 Bradley \& Goldsmith, Customary International Law, supra note i I, at 862-70.

132389 U.S. 429 (I968).

$133 I d$. at 432 . The Zschernig Court invalidated the Oregon escheat statute, which the Oregon courts had applied to deny inheritance to an East German resident. The Supreme Court struck down the law after examining the ways in which the statute required the local probate court to inquire into the makeup of foreign governments, the administration of foreign law, the veracity of diplomatic statements, and the right to receive funds. See $i d$. at 436 .

134 Id. at 443 (Stewart, J., concurring).

135 See, e.g., HENKIN, supra note 46, at 163,436 n.64; Harold Maier, Preemption of State Law: A Recommended Analysis, 83 AM. J. INT'L L. 832, 836 ( 989 ). 
has arguably condoned state action inconsistent with customary norms of international law, or customary international law and state law rules are insufficiently contradictory for a court to give the former preemptive force. ${ }^{136}$

Bradley and Goldsmith, however, make two broader claims. First, they suggest that the federal courts' application of customary international law to states "without the filter of constitutional or legislative authorization" is "inconsistent with the Supreme Court's modern federalism jurisprudence." ${ }^{137}$ But surely nothing in that jurisprudence speaks to "restoring" to the states external foreign affairs powers that were not reserved to them by the Tenth Amendment, and several of which - like the treaty, compact, and agreement powers - were specifically removed from the states by other constitutional provisions. ${ }^{138}$

Second, the authors claim that the Court's recent decision in Barclays Bank PLC v. Franchise Tax Board ${ }^{139}$ demonstrates that the Supreme Court is "back[ing] away" from Zschernig's recognition of federal supremacy in foreign affairs. ${ }^{140}$ In Barclays Bank, after several false starts, ${ }^{141}$ the Court finally upheld California's worldwide combined reporting method for taxing multinational corporations. Noting the wave of foreign protests urging the opposite result, Bradley and Goldsmith optimistically read this decision to hold that all state pronouncements on foreign affairs are presumptively valid, until expressly preempted by a validly enacted federal law.

But the salient fact about Barclays Bank, which Bradley and Goldsmith simply miss, is that the Solicitor General supported California's claim "that the taxes at issue in these cases violated no federal policy and therefore were not unlawfully collected."142 Thus, the case reveals less about the Supreme Court's view of federalism than about the Court's traditional judicial deference to the executive branch in foreign affairs. ${ }^{143}$ As the then-Solicitor General put it:

136 See, e.g., Lea Brilmayer, Federalism, State Authority, and the Preemptive Power of International Law, I994 SuP. CT. REv. 295, 336 (1995) (describing such cases and arguing that there "is a strong but rebuttable presumption that state violations of international law should be invalidated").

137 Bradley \& Goldsmith, Current Illegitimacy, supra note 15 , at 345 .

138 See supra note 5 .

1395 I2 U.S. 298 (I994).

140 Bradley \& Goldsmith, Customary International Law, supra note II, at 865.

141 See, e.g., Franchise Tax Bd. v. Alcan Aluminum Ltd., 493 U.S. 33I, 338-4I (r990) (finding a constitutional challenge to the California franchise tax barred by the Tax Injunction Act); Chicago Bridge \& Iron Co. v. Caterpillar Tractor Co., 4I 7 N.E.2d I343 (IIl. I98I), appeal dismissed, 463 U.S. I220 (I983); Container Corp. v. Franchise Tax Bd., 463 U.S. I59, I93-97 (I983).

142 Brief for United States as Amicus Curiae at 28, Barclays Bank (No. 92-1384). The Bush Administration had previously supported the challenge to the state statute, but the Clinton Administration reversed that position (although not on the issue of the impact of congressional silence). See Barclays Bank, 5 Iz U.S. at 328 n.30.

143 For a discussion of the sources of this deference, see KoH, cited above in note 59, at pages I34-49. 
[T]n the absence of a dispositive statute or treaty, the courts must respect the judgments of the President regarding matters of foreign policy both where the President has determined that state compliance with an international norm is essential and where he has determined that foreign governments should not be allowed to dictate the practices of the States. ${ }^{144}$

Given that neither Congress nor the President asserted that California's taxation policy violated a clear federal policy, the Court declared, "we cannot conclude that 'the foreign policy of the United States - whose nuances ... are much more the province of the $E x$ ecutive Branch and Congress than of this Court - is [so] seriously threatened' by California's practice as to warrant our intervention."145 Only the most wishful thinkers could read this language as some kind of ringing affirmation of states' rights to remake or reject customary international law at will. ${ }^{146}$

One need not denigrate the ability or impartiality of state court judges to recognize that the federal judges have structural attributes that make them more appropriate adjudicators to rule on international matters that may embroil the nation in foreign policy disputes. Unlike state judges, who are effectively unaccountable to national institutions on matters of pure state law, ${ }^{147}$ federal judges are nominated by a national official (the President), are confirmed by a national body (the Senate), are granted salary independence and life tenure, and render federal common law rulings subject to review and revision by federal appellate courts, Congress, and the executive branch. ${ }^{148}$

\footnotetext{
144 Brief for United States as Amicus Curiae at 20, Barclays Bank (No. 92-1384).

145 Barclays Bank, 5 I2 U.S. at 327 (emphasis added) (alteration in original) (citation omitted) (quoting Container Corp. v. Franchise Tax Bd., 463 U.S. 159, I96 (I983)).

146 In my view, the Court could have found a more persuasive basis for the Barclays Bank holding. The Court could have ruled that the federal government had condoned the California state action, and that no clear federal rule barring the worldwide combined reporting method of taxation had ripened under either customary international law or any treaty or statute of the United States. See, e.g., Chantal Thomas, Customary International Lav and State Taxation of Corporate Income: The Case for the Separate Accounting Method, I4 BERKELEY J. INT'L L. 99, 135 (I996) (recounting "substantial evidence" that a separate accounting, as opposed to a unitary tax, method of accounting is a rule of customary international law, but conceding that "some evidence ... suggests the United States may be a 'persistent objector' to, and therefore exempt from, this rule"). Therefore, the Court was not obliged to treat the rule of separate accounting as a principle of federal law with preemptive force over California law.

147 See Erie R.R. Co. v. Tompkins, 304 U.S. 64, 78 ( 1938 ) (declaring that neither Congress nor the federal courts has power to declare or review substantive rules of common law applicable in a state).
}

148 As Professor Hazard notes:

- Federal judges have life tenure, while most state judges do not ....

- Federal judges are appointed by the President of the United States, and confirmed by the United States Senate, and have a commission to prove it, status characteristics that state judges do not have....

- Federal judges are elected by a multi-filter, relatively visible, ultimately high level appointive process, a basis of investiture not enjoyed by most state judges, who are chosen through low visibility nomination and nearly invisible election, except where their selection is by political election.... 
The Framers decided to commit final resolution of constitutional cases to federal judges because they deemed such judges to be "free of the political webs connecting Congress, state legislatures, state courts, and temporary parochial majorities."149 Yet oddly, on matters of international law that implicate parallel federal interests, ${ }^{150}$ Bradley and Goldsmith would give state judges the last word. "In a case in which no clear state law is on point, as will usually be the case in view of the paucity of state court interpretations of $\mathrm{CH}$," they argue, "a federal court sitting in diversity would be required to predict how the highest state court would rule regarding CII's status."151 The import of this bizarre suggestion is that, before the U.S. ratification of the Genocide Convention, a federal judge, faced with the question whether to apply the rules against genocide in a civil tort suit, would have to predict whether the Supreme Court of Tennessee, for example, would incorporate the universal norm against genocide into Tennessee law. Or federal judges sitting in New York diversity actions filed against Imelda Marcos, Lee Teng-hui, Benjamin Netanyahu, Yasser Arafat, or Pope John Paul II would have to guess whether the New York Court of Appeals would accord each or all of these defendants head-of-state immunity. 152

Even those who favor broader federal executive discretion in foreign affairs cannot support the Bradley and Goldsmith thesis. For if their position were the law, how would the President's lawyers advise a visiting head of state about her chances of civil immunity while traveling on a classic State visit from Hawaii, to Williamsburg, Virginia, to Washington, D.C., and to New York (and the U.N. headquarters district)? ${ }^{153}$ Nor does the Bradley and Goldsmith rule help multinational

- Federal judges are part of the United States Government, ... an entire institutional matrix that is a creature of legal rules.

Geoffrey C. Hazard, Jr., Reflections on the Substance of Finality, 70 CORNELL L. REV. 642, 647 (I985).

149 Amar, supra note 30 , at 700 .

150 Cf. Tel-Oren v. Libyan Arab Republic, 726 F.2d 774, 804-05 n.Ir (D.C. Cir. 1984) (Bork, J., concurring) ("A state-court suit that involved a determination of international law would require consideration of ... the principle that foreign relations are constitutionally relegated to the federal government and not the states.").

151 Bradley \& Goldsmith, Customary International Law, supra note II, at $870 \mathrm{n} .345$.

152 To paraphrase Justice Rutledge's dissent in Guaranty Trust Co. v. York, 326 U.S. 99 (1945), if we take states' rights concerns too far in this context, "[t]he next step may well be to say that ... a federal court must surrender its own judgment and attempt to find out what a state court sitting a block away would do." Id. at I 9 (Rutledge, J., dissenting); $f f$. Paul A. Freund, Chief Justice Stone and the Conflict of Laws, 59 HARV. L. REV. I2 IO, I2 I2 (1946) (recalling "that spacious era before the Erie case, when federal judges in diversity cases were more than echoes of half-heard whispers of the state tribunals").

153 It is unclear how such a result would promote the presidential "flexibility" in international affairs so emphasized in Bradley and Goldsmith's separation of powers argument. See supra pp. I84I-42. Indeed it was to forestall such results that the Sabbatino Court wrote:

Whatever considerations are thought to predominate, it is plain that the problems involved are uniquely federal in nature. If federal authority; in this instance this Court, orders the 
national corporations, which must make their business plans based upon the uniformity, predictability, and reliability of judge-made rules. How would a foreign transnational corporation doing business in fifty different states of the Union know, for example, what standard or valuation of compensation it would likely receive if its action for interference with property rights were heard in one state court rather than another? ${ }^{154}$

Bradley and Goldsmith reply that "[i]n fact, states rarely consider issues of CIL, and when they do, they tend to adopt a very deferential attitude toward the federal government's views."155 Yet the claimed urgency of their proposal rests on their prediction that an explosion of "new CIL" will increasingly call upon state courts to make determinations in this area. If, as they say, state courts "tend to adopt" the federal government's views, ${ }^{156}$ the obvious explanation is that state judges feel bound to follow federal interpretations of customary international law! Significantly, Bradley and Goldsmith cite no examples in which the states have complained about a federal court ruling on international law "invading" their sovereignty. This silence strongly suggests that the states do not need or want (or never understood that they had) the power to determine conclusively international law for the United States. ${ }^{157}$

field of judicial competence in this area for the federal courts, and the state courts are left free to formulate their own rules, the purposes behind the doctrine could be as effectively undermined as if there had been no federal pronouncement on the subject.

Banco Nacional de Cuba v. Sabbatino, 376 U.S. 398, 434 (1964).

154 In Banco Nacional de Cuba v. Chase Manhattan Bank, 658 F.2d 875 (2d Cir. I98I), the Second Circuit held under "principles of international, not merely local, law" that an American bank nationalized in Cuba deserved full compensation for its loss, excluding an award of damages for future earnings. Id. at $888,892-93$. Were this rule not binding on the states as federal law, and if no treaty controlled on the matter, a foreign corporation such as Sony or Royal Dutch Shell would have little certainty regarding whether and to what extent it might be entitled to compensation for a state's interference with its property rights in violation of international law. It was to ensure reciprocal certainty for American corporations that the federal courts have declared, pursuant to the act of state doctrine, a federal common law rule limiting the extraterritorial reach of a foreign government's act of expropriation. Cf. Republic of Iraq v. First Nat'l City Bank, 353 F.2d 47, 50 (2d Cir. 1965) ("It would be baffling if a foreign act of state intended to affect property in the United States were ignored on one side of the Hudson but respected on the other; any such diversity between states would needlessly complicate the handling of the foreign relations of the United States.").

155 Bradley \& Goldsmith, Customary International Law, supra note II, at 87 (footnote omitted).

$156 I d$. at $87 \mathrm{I}$.

157 By so saying, I am not denying the authority of state courts to construe their own state laws in light of customary international law. See, e.g., Sterling v. Cupp, 625 P.2d I23, I3I (Or. I98I) (construing the Oregon Constitution in light of U.N. Standard Minimum Rules for the Treatment of Prisoners); Peters v. McKay, 238 P.2d 225, 239 (Or. I95 I). When the appropriate federal court has issued a definitive ruling regarding a customary international law rule, however, that ruling would bind state courts like any other federal common law ruling, subject to congressional revision. 
If the authors' prediction is wrong, and some state judges refuse to "adopt a very deferential attitude toward the federal government's views"158 on the law of treaties, arbitrary detention, or extraterritorial exercises of domestic law, what recourse would the federal government have? Bradley and Goldsmith would likely say, "Congress and the President could pass a statute." But how, realistically, can federal legislators hope to police and correct all erroneous rulings of customary international law in fifty different states? 159

In the end, the question thus becomes: what interests could possibly justify creating an unprecedented new state role in the making, interpretation, and incorporation of international law norms? Here, Bradley and Goldsmith play their final card: "democracy."

\section{DEMOCRACY AND THE LEGITIMACY OF CURRENT INTERNATIONAL HUMAN RIGHTS LITIGATION}

At bottom, Bradley and Goldsmith's complaint reduces to this: "unelected federal judges apply customary international law made by the world community at the expense of state prerogatives. In this context, of course, the interests of the states are neither formally nor effectively represented in the lawmaking process." 160

Again, one might well ask, "So what else is new?" As Professor Neuman has noted, because federal courts have applied customary international law since the beginning of the Republic, "one might think it was rather late to claim that judicial application of customary international law was in principle inconsistent with the American understanding of democracy."161 Moreover, there is absolutely nothing new about unelected judges applying law that was made elsewhere. That is not an indictment but a description of the process of common law judging. ${ }^{162}$ Every court in the United States - including the state courts that Bradley and Goldsmith champion - applies law that was not made by its own polity whenever the court's own choice-of-law

\footnotetext{
158 Bradley \& Goldsmith, Customary International Law, supra note I I, at 87I.

159 Cf. Paul J. Mishkin, The Variousness of "Federal Law": Competence and Discretion in the Choice of National and State Rules for Decision, 105 U. PA. L. REv. 797, 800 (1957). Mishkin explains:

Beyond the political realities which will at times compel congressional by-passing of any issue ... lie such simpler pressures as shortness of time and, perhaps most important, the severe limits of human foresight. Together, these factors combine to make the concept of statutory enactment as a totally self-sufficient and exclusive legislative process entirely unId. real.

160 Bradley \& Goldsmith, Customary Intermational Law, supra note II, at 868 (emphasis added).

161 Neuman, supra note 7 , at 383.

162 See Larry Kramer, The Lawmaking Power of the Federal Courts, I2 PACE L. REv. 263, 272 (I992).
} 
principles so direct. ${ }^{163}$ Nor is there anything inherently undemocratic about judges applying norms of customary law that were made outside the United States. This, too, is something that American judges have done since the beginning of the Republic, whenever they declared rules of customary international law to be part of "general common law."164 In its sixty-year jurisprudence of "new" federal common law, the Supreme Court has never treated the decisions of unelected federal judges as constitutionally illegitimate, as long as the case involved "'uniquely federal interests' [, which were] so committed by the Constitution and laws of the United States to federal control that state law is pre-empted and replaced ... by federal law of a content prescribed by the courts."165

When construing customary international law, federal courts arguably exercise less judicial discretion than when making other kinds of federal common law, as their task is not to create rules willy-nilly, but rather to discern rules of decision from an existing corpus of customary international law rules. ${ }^{166}$ Here, Bradley and Goldsmith charge that state interests are not formally or effectively represented in the customary international lawmaking process. But insofar as customary international law rules arise from traditional State practice, the United States has been, for most of this century, the world's primary

163 See Hiram E. Chodosh, Neither Treaty nor Custom: The Emergence of Declarative International Law, 26 TEX. INT'L L.J. 87, II3 (I99I). Significantly, Bradley and Goldsmith's proposal would also allow unelected federal and state judges to construe customary international law, but as some species of state law. See Neuman, supra note I\%, at 383 ("Absent [s]tate legislative action, the citizens in [s]tates with nonelected judiciaries would be entitled to complain against their [s]tate judges that the judges were undemocratically imposing on them norms derived from a remote international community.").

164 Neuman, supra note 17 , at 389 ("State judges must have been behaving undemocratically through all the years since 1776 when they were applying international law, whether as 'general common law' or as anything else.").

165 Boyle v. United Techs. Corp., 487 U.S. 500, 504 (r988) (quoting Texas Indus., Inc. v. Radcliff Materials, Inc., 45 I U.S. 630,640 (I98I)). For discussions of the legitimacy of federal common lawmaking, see, for example, Stephen B. Burbank, Federal Judgments Law: Sources of Authority and Sources of Rules, 70 TEX. L. REV. I55I, I57 I-87 (1992); and Kramer, cited above in note 162, at page 288 note 84 . As long as a predicate for uniform federal common law rules can be found in the Constitution or acts of Congress, choosing judge-made federal law over state rules has clear benefits. See Burbank, supra, at I58I (stating that if federal and state law are substantially different, "the costs of applying state law would more often include the possible loss of federal substantive rights and thus justify a conclusion that the federal substantive statute requires the application of uniform federal ... law").

166 See Henkin, supra note 3I, at I56I-62 ("In a real sense federal courts find international law rather than make it, ... as is clearly not the case when federal judges make federal common law pursuant to constitutional or legislative delegation."); Koh, supra note 30 , at 2385-86 ("[A]s federal courts have done over the centuries," in such cases, judges "determine whether a clear international consensus has crystallized around a legal norm that protects or bestows rights upon a group of individuals that includes plaintiffs."). In the modern human rights cases, for example, federal courts have regularly demanded that the customary international law norm being invoked be universal, definable, and obligatory before allowing an actionable claim under the Alien Tort Claims Act. See Goodman \& Jinks, supra note I7, at 495-97 (collecting decisions). 
maker of and participant in this practice. Increasingly, multilateral treaty drafting processes and fora such as the United Nations, regional fora, standing and ad hoc intergovernmental organizations, and diplomatic conferences have become the driving forces in the creation and shaping of contemporary international law. ${ }^{167}$ In nearly all of these organizations and fora, the United States ranks among the leading participants.

Notwithstanding the executive branch domination of foreign affairs, in every foreign policy decisionmaking process, one can find multiple channels for congressional participation and state representation. These include, but are not limited to, such oversight and input mechanisms as hearings, markups, congressional consultations, committee approval devices, and the like. ${ }^{168}$ When customary international law rules arise from a treatymaking process, or from a treaty regime, ${ }^{169}$ congressional interests are often directly represented at the negotiating table. ${ }^{170}$ Even. when Members of Congress are not allowed to participate directly in such treaty negotiations, the knowledge that any negotiated agreement must return to Congress for ratification necessarily pervades the executive branch's negotiating position. ${ }^{171}$

Bradley and Goldsmith nowhere explain why explicit federal legislation - a process notoriously dominated by committees, strongwilled individuals, collective action problems, and private rentseeking ${ }^{172}$ - is invariably more democratic than the judge-driven process they criticize. ${ }^{173}$ Nor do they explain why state courts would act

167 See Jonathan I. Charney, International Agreements and the Development of Customary Intemational Law, 6I WASH. L. REV. 97 I, 975-84 (I986) (discussing the modern role of these agreement-making processes and fora for the development of customary international law); Jonathan I. Charney, Universal International Law, 87 AM. J. INT'L L. 529, 543 (I993).

168 See generally Harold Hongju Koh, The Fast Track and United States Trade Policy, 18 BRoOK. J. INT'L L. I43, I6I 7 I (I992) (rejecting a similar "democracy" objection and noting numerous leverage points whereby congressional views may be factored into the executive decision).

169 See generally Abram Chayes \& Antonia Handler Chayes, The New Sovereignty: COMPLIANCE WITH INTERNATIONAL REgULATORY AGREEMENTS I12-53 (1995) (describing how this customary rule-making process unfolds).

170 See Koh, supra note I68, at I53 (noting that direct congressional participation in trade negotiations has occurred since 1974). Such a direct congressional role has a long history. President McKinley, for example, named three senators as members of the peace commission that negotiated the end of the Spanish-American War. See KoH, supra note 59, at $9 \mathrm{r}$.

171 See generally Koh, supra note I68 (describing multiple channels for congressional input into the trade negotiation process via the fast track legislative mechanism).

172 The literature on this subject, too, has killed several forests. See generally JERRY L. Mashaw, Greed, Chaos, and Governance: Using Public Choice to Improve Public LAW 200-OI (I997) (arguing that public choice theory is of limited value). For a discussion of institutional factors influencing congressional decisionmaking in foreign affairs, see KoH, cited above in note 59 , at pages $117-33$.

173 Professor Kramer put it well:

[T] ]he fact [is] that large numbers of people are and always have been formally or practically disenfranchised. Indeed, public choice scholarship suggests that even our "representative" bodies are often wildly unrepresentative. Add to that the independent administrative agencies that make so much law today, and the huge advantages that seem to flow 
more democratically than federal courts in deciding customary international law cases. The Founders recognized that "democratic" values are poorly served by permitting the courts of one state of the Union to issue rulings that could potentially embroil the entire nation in international controversies. ${ }^{174}$ If, for example, a Massachusetts judge issued a ruling on head-of-state immunity that triggered an international dispute between the U.S. and the United Kingdom, the citizens of every other state would potentially suffer from the unelected state judge's actions. Even under Bradley and Goldsmith's standards, it is hard to imagine a more undemocratic result.

Under the traditional view, federal common law rules of customary international law are perennially subject to a democratic check: supervision, revision, and endorsement by the federal political branches. Take, for example, the federal common law rule of comity in international antitrust cases. ${ }^{175}$ This rule was first articulated as a principle of general common law, ${ }^{176}$ which then-Professor Kingman Brewster redefined in his international antitrust treatise as a so-called "jurisdictional rule of reason."177 In Timberlane Lumber Co. v. Bank of America, ${ }^{178}$ the Ninth Circuit applied Brewster's analysis to permit U.S. regulation of extraterritorial conduct through an interest-balancing test, which other federal courts then applied as a judicial "brake" on the extraterritorial exercise of U.S. prescriptive jurisdiction. ${ }^{179}$ In time, the American Law Institute's Restatement (Third) of Foreign Rela-

from incumbency and access to capital, and the clear contrast between "representative" legislatures and "unrepresentative" judges begins to look rather murky. Unless we ignore these flaws, the criticism made of [federal] common lawmaking can just as easily be leveled at the process by which most law, including ordinary legislation, is made.

Kramer, supra note 162 , at 272 .

174 See supra pp. I840-4I.

175 See Harold Maier, International Comity and U.S. Federal Common Law, I9go PROC. AM. Soc. INT'L L. 326, 342 (I99I) ("If the federal common law process ... is accurately described as the application of general principles to specific fact situations to arrive at legal results, then the principle of comity is surely one of those general principles.").

176 See Hilton v. Guyot, I59 U.S. I I3, I64 (I895) (defining comity as "the recognition which one nation allows within its territory to the legislative, executive or judicial acts of another nation, having due regard both to international duty and convenience, and to the rights of its own citizens or of other persons who are under the protection of its laws").

177 KINGMaN BREwSTer, JR., ANTITRUST AND AMERICAN BUSINESS ABROAD 446 (I958). For a history of Brewster's role in developing the test later adopted in Timberlane, see Spencer Weber Waller, Antitrust and American Business Abroad Today, 44 DEPAUL L. REV. I25 I (I995).

178549 F.2d 597 (9th Cir. r976).

179 See id. at 608-13 (linking interest-balancing to effects doctrine of United States v. Alcoa, I48 F.2d 4I6 (2d Cir. I945)); see also O.N.E. Shipping Ltd. v. Flota Mercante Grancolombiana, S.A., 830 F.2d 449, 45I-53 (2d Cir. 1987) (adopting a variant of the Timberlane test); Montreal Trading Ltd. v. Amax Inc., 66r F.2d 864, 869 (Ioth Cir. I98I) (same); In re Uranium Antitrust Litig., 6I7 F.2d 1248, 1255-56 (7th Cir. I980) (same); Mannington Mills, Inc. v. Congoleum Corp., 595 F.2d 1287, 1297-98 (3d Cir. 1979) (same). For examples from the securities context, see Consolidated Gold Fields PLC v. Minorco, S.A., 87I F.2d 252 (2d Cir. 1989); Data Processing Equip. Co. v. Maxwell, 468 F.2d I326 (2d Cir. I972); and Schoenbaum v. Firstbrook, 405 F.2d 200 (2d Cir. 1968). 
tions Law adapted Timberlane's interest-balancing test to aid determination of when a nation's exercise of prescriptive jurisdiction is or is not "reasonable," and the United States and foreign governments have begun to follow suit. ${ }^{180}$

This story illustrates that federal common law rulemaking in international affairs is a critical element of the process of transnational legal rulemaking, which I have elsewhere called "transnational legal process."181 In this process, no bright line separates domestic rules of decision (such as the act of state doctrine, which Bradley and Goldsmith acknowledge is federal law) from the rules of customary international law, which the authors would subject to state and political branch supervision. International comity represents a principle with roots in both common law and international law, which now may be evolving into a rule of customary international law. ${ }^{182}$ Whether viewed as a rule of statutory construction or justiciability, or a principle of reasonableness, international comity clearly should be treated as a doctrine of federal law, capable of revision by Congress, the executive branch, or the federal courts, as circumstances demand. ${ }^{183}$ But

180 See Restatement (THIRD), supra note $82, \S 403$. The ResTATEMENT (THIRD) test differs from that in Timberlane in treating comity as an inherent limit on the prescriptive, legislative jurisdiction of Congress, not on the adjudicative jurisdiction of the federal courts. The Department of Justice's 1988 and I995 Antitrust Enforcement Guidelines for International Operations specifically contemplate the use of a comity-based balancing test to guide the extraterritorial prosecution of U.S. antitrust laws. See U.S. DePT. OF Justice and Federal Trade Commission, ANTITRUST ENFORCEMENT GUIDE LINES FOR INTERNATIONAI OPERATIONS '3.1 (r995); U.S. Department of Justice, Antitrust Enforcement Guidelines for International Operations, 55 ATRR SPEClal SUPP. 32 (Nov. I7, I988); see also Foreign Trade Antitrust Improvements Act, I5 U.S.C. $\S 6$ (a) (r994) (applying U.S. antitrust law to certain foreign monopolistic conduct, without altering courts' freedom to employ notions of comity). For a discussion of the growing convergence of U.S. and European anti-competition laws, see, for example, Roger Alford, The Extraterritorial Application of Antitrust Laws: A Postscript on Hartford Fire Insurance Co. v. California, 34 VA. J. INT'L L. I, 27-37 (I992).

181 Harold Hongju Koh, Transnational Legal Process, 75 NEB. L. REv. 18I, 18I (I996); sec Harold Hongju Koh, Why Do Nations Obey International Law?, IO6 YALE L.J. 2599 (1997) [hereinafter Koh, Why Nations Obey]. For another example, see page 1839, discussing the evolution of the doctrine of foreign sovereign immunity.

182 A substantial debate currently rages over whether comity, reasonableness, or interestbalancing constitute rules of customary international law, as opposed to a national principle of judicial deference. See David B. Massey, How the American Law Institute Influences Customary Law: The Reasonableness Requirement of the Restatement of Foreign Relations Law, 22 YALE J. INT'L L. 4I9 (I997); Karl M. Meessen, Antitrust Jurisdiction Under Customary International Law, 78 AM. J. INT'L L. 783 (I984).

183 The customary international law rule of "prompt, adequate, and effective" compensation for expropriation provides another illustration of evolution through transnational legal process. The rule was first announced in an executive branch letter written by Cordell Hull in 1938 and had not been sufficiently crystallized to be deemed a rule of customary international law in Sabbatino. See Banco Nacional de Cuba v. Sabbatino, 376 U.S. 398, 428-30 (1964). But as the years went on, the standard was embodied in bilateral investment treaties, executive branch statements, and federal statutes, and was recognized by international judicial and arbitral tribunals. In 1985 the Second Circuit had come to recognize that standard as the controlling standard in an expropriation case. See supra note ${ }_{154}$ (discussing Banco Nacional de Cuba v. Chase Manhattan Bank, 658 
under Bradley and Goldsmith's reasoning, comity, like the act of state doctrine, could be treated as federal common law only until it ripened into a rule of "new" customary international law, at which point the authors would relegate it to state supervision!

Nor is anything unusual, much less conspiratorial, about academics, federal courts, executive officials, Congress, and foreign governments' interacting in a variety of private and public, domestic and international fora to make, interpret, internalize, and ultimately enforce rules of transnational law. To the contrary, it is precisely through this transnational legal process that interlinked rules of domestic and international law develop, and that interlinked processes of domestic and international compliance come about. ${ }^{184}$

Bradley and Goldsmith view this traditionally fluid, accretive, osmotic process of legal internalization - whereby some rules become international law through treaty, others through custom, and others remain rules of domestic law - as somehow threatening to state interests. Particularly claims of international human rights, they suggest, so invade state prerogatives that such claims should be presumptively barred from domestic law unless formally adopted by express political branch authorization. Under this world view, the time-honored dialogic process, whereby jurists, publicists, and academic commentators (such as the American Law Institute) seek - through writing, teaching, and amicus briefs - to inform, influence, and improve judicial decisionmaking, becomes a shady process of undue influence, "academic fiats," and doctrinal bootstrapping. ${ }^{185}$ This view deems international human rights litigation in U.S. courts illegitimate because the traditional process of fashioning federal common law rules of customary international law "permits federal courts to accomplish through the back door of CIL what the political branches have prohibited through the front door of treaties."186

In my view, the law is not nearly so mechanistic and the world is not nearly so sinister. Bradley and Goldsmith have stumbled into what Professor Maier once described as the "power struggle image" of state-federal conflict in foreign affairs: "a presently outmoded and ... initially erroneous concept of the states and the national government as competing sovereigns, vying for the right to control the national

F.2d 875 (2d Cir. 198I)). For materials tracing the evolution of the compensation rule in expropriation cases, consult STELNER, VAGTS \& $\mathrm{KOH}$, cited above in note 77 , at pages $45 \mathrm{I}-505$.

184 See Koh, Why Nations Obey, supra note I8I, at 2645-59 (illustrating how transnational legal process promotes compliance).

185 See, e.g., Bradley \& Goldsmith, Customary Intermational Lave, supra note II, at 874-76 (expressing concern about the influence of academics on judges in customary international law cases).

186 Bradley \& Goldsmith, Current Illegitimacy, supra note I5, at 330-3I. 
destiny."187 This zero-sum image of state-federal competition leads Bradley and Goldsmith to downplay the multiple channels through which international human rights norms trickle down to the states from the federal government, and whereby states signal their concerns about state prerogatives to the federal entities. ${ }^{188}$ It also makes them unduly suspicious of private actors, such as nongovernmental organizations and activists, who play an increasingly important role in any transnational legal process. ${ }^{189}$ Like the police chief in Casablanca, Bradley and Goldsmith cannot seriously be "shocked" to find courts looking to academic writing for guidance in international law cases. ${ }^{190}$ If anything, the influence of law and economics scholars over American antitrust law has been far more pervasive than the influence of international law scholars on American international human rights jurisprudence, and through similar processes of intellectual influence. ${ }^{191}$ And why should federal judges, who are protected by constitutional guarantees of independence and sworn to uphold the laws of the United States, be so easily misled by the law professors who write and appear before them? ${ }^{192}$

187 Harold G. Maier, The Bases and Range of Federal Common Law in Private International Matters, 5 VAND. J. TRANSNAT'L L. I33, I63 (I97I).

188 This process is illustrated in the Barclays Bank case, discussed above in notes $139-146$ and accompanying text.

189 See generally Harold Hongju Koh, The Ig98 Frankel Lecture: Bringing International Laws Home, 35 Hous. L. REv. (forthcoming Oct. I998) (manuscript at 23-26, on file with author) (expanding on the role of transnational norm entrepreneurs in transnational legal process); Koh, Why Nations Obey, supra note I8I, at $26 \mathrm{I} 2 \mathrm{n} .53$ (discussing that role).

190 As Bradley and Goldsmith recognize, see Bradley \& Goldsmith, Customary International Law, supra note II, at $875 \mathrm{n}$. 36r, for nearly 200 years, U.S. courts deciding international law cases have looked to "the work of jurists and commentators, who by years of labor, research, and experience have made themselves peculiarly well acquainted with the subject of which they treat." The Paquete Habana, I75 U.S. 677 , 700 (I900). Article 38.I(d) of the Statute of the International Court of Justice, June 26, I945, 59 Stat. I055, 1060, 3 Bevans II53, I187, expressly declares that "the teachings of the most highly qualified publicists of the various nations ... [are] subsidiary means for the determination of [international] law." Id. at I 187 ; see also United States v. Smith, I8 U.S. (5 Wheat.) I53, I60-6I (I820) ("What the law of nations on this subject is, may be ascertained by consulting the works of jurists, writing professedly on public law; or by the general usage and practice of nations; or by judicial decisions recogni[z]ing and enforcing that law."); Filartiga v. Pena-Irala, 630 F.2d 876, 880-81 (2d Cir. 1980). In Filartiga, the court declared: "The Paquete Habana reaffirmed that ... the works of jurists and commentators ... are resorted to by judicial tribunals, not for the speculations of their authors concerning what the law ought to be, but for trustworthy evidence of what the law really is." Id.

191 Prominent antitrust scholars such as Robert Bork and Richard Posner have taken to the bench, and others such as William Baxter and Donald Turner have worked in the Justice Department. Still other academics, such as Phillip Areeda, have influenced the development of antitrust law largely through their writing and consulting.

192 For example, Bradley and Goldsmith's curious final footnote points to the fact that several "proponents of the modern position," including me, have lectured to judges about international human rights law over the past few years at the Aspen Institute. See Bradley \& Goldsmith, Customary Intemational Law, supra note II, at 876 n.365. Yet this observation proves no more than the equally true fact that I lectured on Procedure and International Law to my friend, Professor Goldsmith, when he was a student at Yale Law School. Presumably, the judges in these human 
Bradley and Goldsmith's misunderstanding of process also leads them to attack current international human rights litigation, based on the mistaken notion that such litigation rests on a "new," subversive form of customary international law. The political branches, they suggest, have appropriately incorporated most of the "old" customary international law into U.S. domestic law, while properly resisting incorporation of the "new," less democratic human rights law. To reinforce this gatekeeping function, they argue, the entire tradition of treating customary international law as federal law ought now be deemed constitutionally illegitimate.

Initially, Bradley and Goldsmith took pains to concede the existence of some legitimate avenues through which human rights litigation might be sustained. ${ }^{193}$ They acknowledged a range of theories under which federal courts could, consistently with separation of powers, construe these statutes to create federal common law rules of civil liability to redress international crimes. ${ }^{194}$ But in response to their critics, they have hardened their position and moved to categorical declarations about the "current illegitimacy of international human rights litigation" under the ATCA and the TVPA. ${ }^{195}$

Given that others have fully rebutted the specifics of their challenge, I need not repeat those arguments here. ${ }^{196}$ Suffice it to say that no clear line separates the "old" from the "new" customary international law because both have influenced American law through precisely the same transnational legal process. ${ }^{197}$ Nor is there anything "modern," unconstitutional, or undemocratic about the way that human rights norms - in contrast to any other norms of customary international law - have entered American law. It was largely through American political leadership that human rights norms first entered

rights seminars have reached their own independent views about the domestic status of customary international law, in the same way that Professor Goldsmith has reached his.

193 They argued that adoption of their viewpoint and "rejection of the modern position would not necessarily spell the end for modern human rights litigation." Bradley \& Goldsmith, Customary International Law, supra note II, at 872 .

194 See id. at 872-73 \& nn.352-56.

195 Bradley \& Goldsmith, Current Illegitimacy, supra note 15, at 319 . In particular, they have examined, and found insufficient, Congress's "explicit political authorization" of international human rights litigation in the ATCA and the TVPA. Id. at 356.

196 See Goodman \& Jinks, supra note 17 , at 513-28.

197 Bradley and Goldsmith claim that the "new CIL" of human rights somehow differs fundamentally from "traditional CII," inasmuch as "[i]t is less tied to state practice, it can develop rapidly, and it increasingly purports to regulate a state's treatment of its citizens." Bradley \& Goldsmith, Customary International Law, supra note II, at 842 . But precisely the same could be said of the ancient lex mercatoria, which was tied to the practice of business among the Mediterranean states, developed rapidly, and was often applied as internal domestic law, as was shown in Sreift v. Tyson itself. See Harold J. Berman \& Colin Kaufman, The Law of International Commercial Transactions (Lex Mercatoria), I9 HARV. INT'L L.J. 22I, 224-29 (I978); sources cited supra note 32. 
the discourse of international law, and through American courts that many of those norms have been substantially advanced.

Whether "old" or "new," international law norms do not bind federal courts until they have ripened into customary law rules. Sometimes, as in the case of the United Nations Convention on the Law of the Sea, the executive branch takes the lead in incorporating such norms into U.S. law. Sometimes Congress takes the lead, spurred by nongovernmental organizations. ${ }^{198}$ In recent human rights cases, federal courts have taken the lead, but only with the express congressional directives in the ATCA and the TVPA.

We should not forget that all three branches of the federal government have a say in deciding whether international human rights cases will proceed to final judgment in U.S. courts. Federal judges need not apply overbroad jurisdictional rules that dismiss all international human rights cases as inherently unfit for domestic adjudication. Instead, they may address the valid concerns that may arise involving comity, separation of powers, and judicial incompetence through "doctrinal targeting": case-by-case application of existing doctrines to particular norms and fact patterns. ${ }^{199}$ The executive branch may, and frequently does, appear before the courts to urge particular outcomes in human rights cases. ${ }^{200}$ When the executive branch has appeared, it has accepted neither Bradley and Goldsmith's claim about the illegitimacy of such litigation, nor their broader assertion about the nonfederal status of customary international law. Finally, as Judge John M. Walker, Jr. has recently noted:

[The ATCA] is simply an act of Congress. If it raises valid policy concerns and if adjudication under it leads to real-world problems for the executive or the legislature, it may be amended, or even repealed. The fact that Congress has not done so, and, indeed, appears to have endorsed the $\mathrm{Fi}$ lartiga approach in the legislative history of the Torture Victim Protection Act, indicates that the substantial concerns that have been voiced are, at least at this point, largely theoretical. This minimizes any worry that the judiciary, while finding specific authority in a specific Congressional enactment, has somehow embarked on a course of permitting a remedy for human rights violations that Congress never intended, or that will unduly interfere with the functioning of the other branches of government. ${ }^{201}$

\footnotetext{
198 See supra notes 83 (law of the sea), Iog (legislation incorporating international law norms at the urging of human rights non-governmental organizations). For a parallel discussion of the respective role of the courts, executive, legislature, and private actors in promoting the pending incorporation of the European Convention of Human Rights into United Kingdom law, see Koh, Why Nations Obey, cited above in note $\mathrm{I} 8 \mathrm{I}$, at page 2658 .

$199 \mathrm{Koh}$, supra note 30, at 2382-94 (outlining how judges applying common law and procedural doctrines may dispose of inappropriate human rights cases that may appear on their dockets).

200 See, e.g., Filartiga v. Pena-Irala, 630 F.2d 876 (2d Cir. I980); supra notes 96-ro4.

201 The Honorable John M. Walker, Jr., Domestic Adjudication of Intemational Human Rights Violations Under the Alien Tort Statute, 4I ST. Louis U. L.J. 539, 560 (1997).
} 


\section{CONCLUSION}

At the end of the day, Bradley and Goldsmith miss both their large and their small targets. History, doctrine, the Constitution, and "democracy" all fail to support their broader claim that at this late date, customary international law should be ousted from federal law. If their real target is current human rights litigation, that practice also rests on firmly established historical, legislative, and doctrinal footings.

On examination, Bradley and Goldsmith's thesis should lack appeal even for those who fully embrace their values. Treating international law as some species of state law does not foster original intent, states' rights, judicial restraint, executive discretion, or democratic decisionmaking.

When all is said and done, my point is simple: conventional wisdoms are often right. "International law is federal law" is one example. "If it ain't broke, don't fix it" is another. 